Publication Draft

Not to be cited without permission

\title{
Economic Integration of Eurasia: Opportunities and Challenges of Global Significance
}

\author{
Johannes F. Linn and David Tiomkin \\ The Brookings Institution and Harvard University \\ Jlinn@brookings.edu and david_tiomkin@ksg06.harvard.edu
}

June 2005

Prepared for Publication by Cambridge University Press in

EUROPE AFTER THE ENLARGEMENT

Edited by Anders Aslund and Marek Dabrowski

\begin{abstract}
$\underline{\text { Abstract }}$
After the collapse of the Soviet Empire in 1991 a new frontier in the process of globalization of the world economy opened up: the economic integration of the Eurasian "super-continent". This paper explores the process and prospects of integration of the huge land-mass that stretches from the Atlantic to the Pacific Oceans and from the Arctic Sea to the Indian Ocean. The paper focuses principally on the economic dimensions and significance of the integration process of Eurasia. It compiles evidence on Eurasian integration in the areas of energy and non-energy trade and transport, illicit drug trade, investment and capital flows, migration, and communication and knowledge. It concludes with a consideration of the institutional and political dimensions that affect regional cooperation for Eurasia and with some broad policy recommendations.
\end{abstract}




\title{
Economic Integration of Eurasia: Opportunities and Challenges of Global Significance
}

\author{
Johannes F. Linn and David Tiomkin*
}

\begin{abstract}
After the collapse of the Soviet Empire in 1991 a new frontier in the process of globalization of the world economy opened up: the economic integration of the Eurasian "super-continent". This paper explores the process and prospects of integration of the huge land-mass that stretches from the Atlantic to the Pacific Oceans and from the Arctic Sea to the Indian Ocean. ${ }^{1}$ This paper focuses principally on the economic dimensions and significance of the integration process of Eurasia. It compiles evidence on Eurasian integration in the areas of energy and non-energy trade and transport, illicit drug trade, investment and capital flows, migration, and communication and knowledge. It concludes with a consideration of the institutional and political dimensions that affect regional cooperation for Eurasia and with some broad policy recommendations.
\end{abstract}

The Eurasian continental space was integrated for centuries, if not millennia, before the arrival of modern times. Anthropologists speculate that much of modern humanity originated in and spread from the Mongolian steppes millions of years ago. These very early sweeps were followed from the East by waves of conquerors, among them Attila the Hun and Genghis Khan. ${ }^{2}$ The Great Silk Road (represented in a stylized manner in Figure 1) serves as the epitome of Eurasian economic and cultural connectedness, as it spread East-West from the Chinese Sea through Central Asia, the Mediterranean on to Western Europe, connecting also the Indian Subcontinent and the northern reaches of what is Russia today (Hopkirk, 1980). Commerce, culture and religion spread along this route, as did conflict and disease, including the Black Death of the mid- $14^{\text {th }}$ Century. ${ }^{3}$

\footnotetext{
* The authors are respectively Visiting Fellow at the Brookings Institution and MBA and MPA/ID candidate at Harvard University. They gratefully acknowledge the comments of participants in a seminar at the World Bank and at the CASE International Conference in Warsaw in April 2005. They also received valuable comments from Anders Aslund, Peter Thomson and Jakob von Weiszaecker.

${ }^{1}$ The geographic concept of "Eurasia" is here defined to include all of the traditional geographic areas of Europe and Asia, excluding the Arab peninsula, but including Turkey, Iran and Afghanistan, with the latter two referred to as “Asia Minor” in considering regional sub-groupings. This geographic boundary is of course arbitrary, but for economic, cultural and political reasons it is for the purposes of this paper preferable to consider the Arab Peninsula as part of the geographic and economic region of Middle East and North Africa.

2 The empire of Genghis Khan "stretched from the snowy tundra of Siberia to the hot plains of India, from the rice paddies of Vietnam to the wheat fields of Hungary, and from Korea to the Balkans.... [He] opened roads of commerce in a free-trade zone that stretched across the continents... He took the disjoined and languorous trading towns along the Silk Route and organized them into history's largest free-trade zone.” (Weatherford, 2004, pp. xviii-xix). Of course, conquerors moved across Eurasia also from the West, including Alexander the Great and later various Islamic leaders from the Arab Peninsula.

${ }^{3}$ A recent history of the Great Plague puts it as follows: “... the plague bacillus, Yersinia pestis, swallowed Eurasia the way a snake swallows a rabbit - whole, virtually in a single sitting. From China in the East to Greenland in the West, from Siberia in the North to India in the south, the plague blighted lives everywhere...” (Kelly, 2005, quoted in The Wall Street Journal Europe, February 25-27, p. P4)
} 
Figure 1: The Ancient Silk Road

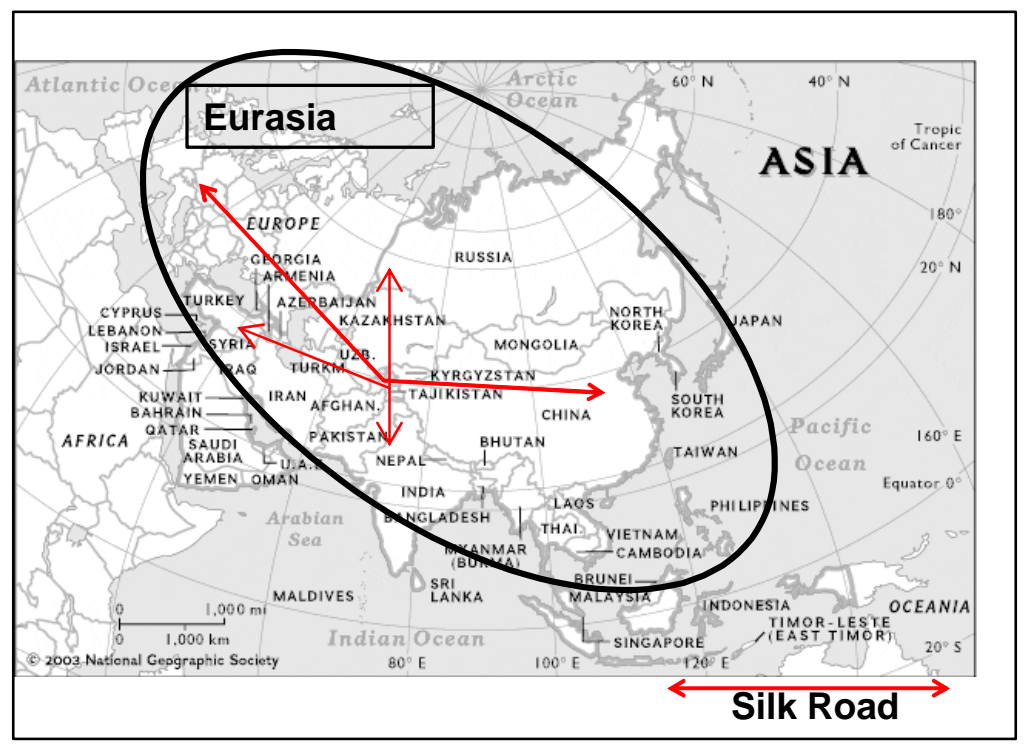

Many factors contributed to the eventual disintegration of the Eurasian economic space and in particular the decline in overland communications - the decline of the great empires in and around Central Asia, a rise in instability in key regions along transit routes (especially the Caucasus and Central Asia), and the emergence of a weak and fractious China. In addition, the rise of the Tsarist Russian Empire and the expansion of Western European colonial powers in East and South East Asia created borders across the Eurasian continental space and the introduction of the steam ship and the opening up of the Suez Canal made the sea routes more attractive and economical. Finally, the rise of Communism and the erection of the Iron and Bamboo Curtains sealed off much of the Central and Eastern parts of the Eurasia from the rest of the continental space and from the rest of the world.

After World War II it was common to characterize the world as falling into three parts: the Western industrial countries; the Eastern Bloc, consisting of the Soviet Union, its satellite states and of China; and the South, or Third World countries, which emerged as part of the post-war decolonization process. Beginning with the 1950s, the West's economies rapidly integrated broadly on market principles. The West also pulled along gradually, if imperfectly, the South in this integration process. By contrast, the East did not participate in this economical globalization process, although much of the region was highly integrated internally within the Soviet Empire. Moreover, the 40 year period of 1950-90 was characterized by a high degree of geopolitical, military and ideological competition and tension among the Western and Eastern protagonists as part of the "Cold War”.

In the 1980s a major shift in the geopolitical constellations began. In the early 1980s China opened up politically and economically, followed after 1985 by a loosening of political and economic controls in the Soviet Union under its last leader, Mr. Gorbachev. 
This in turn led to the dramatic, albeit largely peaceful dissolution of the Soviet Empire between 1989 and 1991 and the transition to market economic systems in the former Communist countries. These developments and the continued rapid process of global economic integration had two major interrelated consequences:

First, the world no longer could be characterized as falling into three separate blocs; rather, it is now a highly interdependent political and economic system, although some countries and regions are at risk of being marginalized (especially Africa) or subject to chronic conflicts (Middle East).

Second - and this is the point of departure for our analysis in this paper -, the previously hard borders between the Western, Eastern and Southern parts of Eurasia gradually opened up. With this the opportunities for economic integration throughout Eurasia dramatically increased. Of course, this process has only started. It still has to overcome many obstacles, not least the consequences of the disintegration of the Soviet Empire which led to the creation of new borders, the fracture of traditional economic links among the countries of the Former Soviet Union and a deep economic collapse in the newly created states of the Commonwealth of Independent States (CIS) (Linn, 2004).

The integration of the Eurasian super-continent will have major potential implications not only for the Eurasian region, but for the world economy, because of the sheer size and weight of the Eurasian economic space. In terms of demography, Eurasia in 2004 accounted for $69 \%$ of the world's population. Over time, this share is expected to decrease somewhat, as the overall population of the region grows less rapidly than for the rest of the world. Nonetheless, by 2050, the region is projected to still be home to almost 2/3 of the world's population (Figure 2 ).

\section{Figure 2: Global Population Growth and Composition}
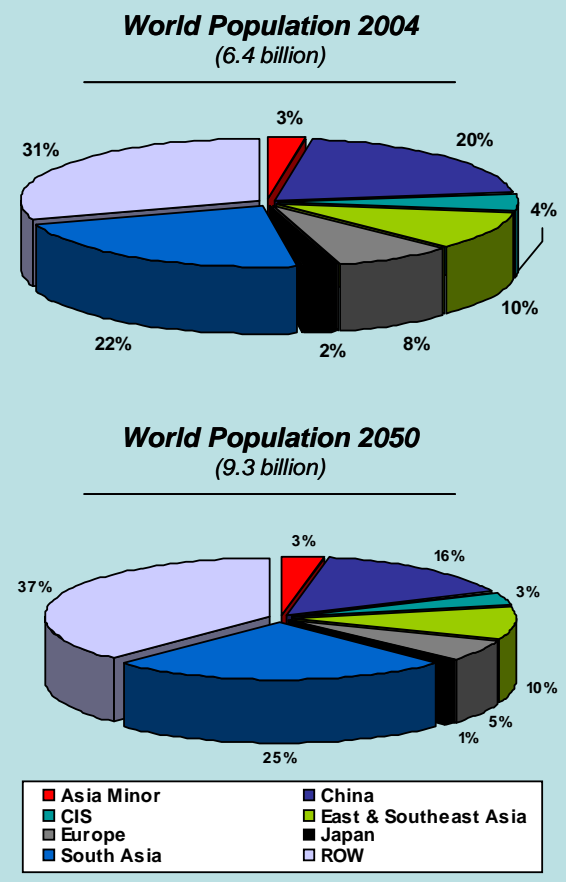

Population Growth 2004-2050

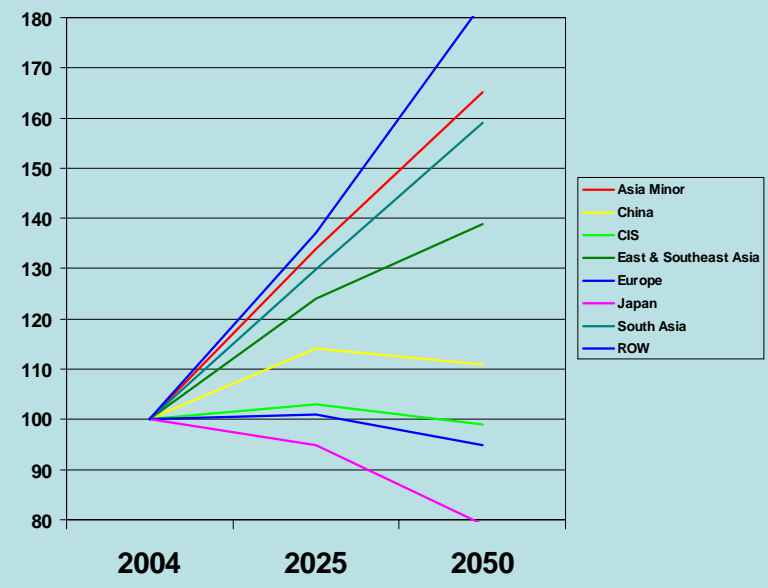

Source: PRB 2004 World Population Data Sheet. 
In terms of its economic size, Eurasia currently accounts for about 53\% of World GDP in current US dollars. ${ }^{4}$ For the future much will depend on whether the developing and transition countries of Eurasia - East Asia, South Asia and Eastern Europe and Central Asia - will maintain their exceptionally high growth rates of recent years on the one hand, and whether the industrialized countries of the region - Japan and Western Europe - can recover from the economic stagnation that has gripped them over the last decade. ${ }^{5}$ But there can be no doubt about the economic and political ascendancy of China and India. China is projected to exceed all its Eurasian competitors in economic size by the year 2016 and surpass the US sometime in the early 2040s. India is projected to reach the former benchmark by the early 2030s (Wilson and Purushothaman, 2003). If Europe and Japan can turn around their economic fortunes and reap the potential benefits of economic integration with their dynamic continental neighbors, then the Eurasian economy may well approach the $60 \%$ mark or higher in terms of its share in the world economy by 2050. According to one set of projections, the GDPs of China, India, Russia, France, Germany, Italy, Japan, and the UK combined will exceed that of the US by $2 \frac{1}{2}$ times in 2050 (Wilson and Purushothaman, 2003).

The remainder of this paper discusses how the economic integration process in Eurasia is proceeding in six key areas ${ }^{6}$ :

- Energy Trade and Transport

- Non-Energy Trade and Transport

- Trade in Illicit Drugs

- Investment and Capital Flows

- Migration

- Communication and Knowledge

The paper also reviews briefly the institutional framework for integration in Eurasia and the possible tensions between political and economic dimensions of the integration process. It concludes with some observations on possible policy implications. The paper remains exploratory. Many of the ideas presented should be taken as hypotheses which are only partially tested by the analysis and the data presented in the paper.

One final caveat: By focusing the spot light in this paper on Eurasia, we do not want to belittle the importance of the links between Eurasia and its major sub-regions and the rest of the world, or that integration of other regions of the world - Africa, the Americas, the Middle East, and Oceania - do not present important challenges. Our core point is that integration in Eurasia, after a long delay, is catching up with the world-wide process of integration and will likely create significant opportunities and challenges for the region as well as globally.

\footnotetext{
${ }^{4}$ Based on the World Bank’s World Development Indicators, 2004

${ }^{5}$ The developing countries of East Asia and the Pacific grew at a rate of $7.7 \%$ in 2003, those of South Asia 7.4\%, and those of Europe and Central Asia 6.0\%. Japan grew at 2.1\% and Western Europe at about 1\%. The US grew at 2.9\%, and the World economy at 2.5\% (World Bank, World Development Indicators 2004).

${ }^{6}$ There are other areas that could be considered in terms of their relevance as region-wide integrating factors or concerns, including tourism development, environmental and natural resource (esp. water) management, crime and terrorism.
} 


\section{Energy Trade and Transport}

The single most important force of economic integration today in Eurasia is the linkage of major oil and natural gas reserves in Russia and around the Caspian Sea with the markets in Western Europe and increasingly in East and South Asia. In fact, the rapid growth of energy exports has been one of the main drivers of the recent CIS economic recovery (Hill 2004). Further substantial increases in oil production and exports are projected for Russia, Azerbaijan and Kazakhstan by 2010. ${ }^{7}$ In addition to production and exports from the CIS, there are other important energy links in Eurasia, including from Indonesia to East Asia and potentially from Burma to India.

According to BP (2004), Eurasia accounted for around 36\% of global oil production and just over $50 \%$ of global natural gas production in 2003. During the same year the region consumed around $55 \%$ and $57 \%$ of the world's oil and natural gas. For electricity there is until now only a small cross-border market within Europe and among European countries a (Figure 3). Most Eurasian trading blocs are net importers of energy, in particular Japan and South Asia, which export virtually no energy products. Figures 4 and 5 depict the flows of oil and gas trade, showing that Russia and Central Asia supply the lion's share of European oil imports, while the Middle East supplies the majority of Asia's oil (BP 2004). For natural gas, flows are primarily from the CIS and northern Europe to the rest of Europe and from Southeast Asia and the Middle East to much of the rest of Asia. Transatlantic and transpacific energy flows are relatively minor.

Figure 3: Energy Imports and Exports to/From Eurasian Countries in 2003

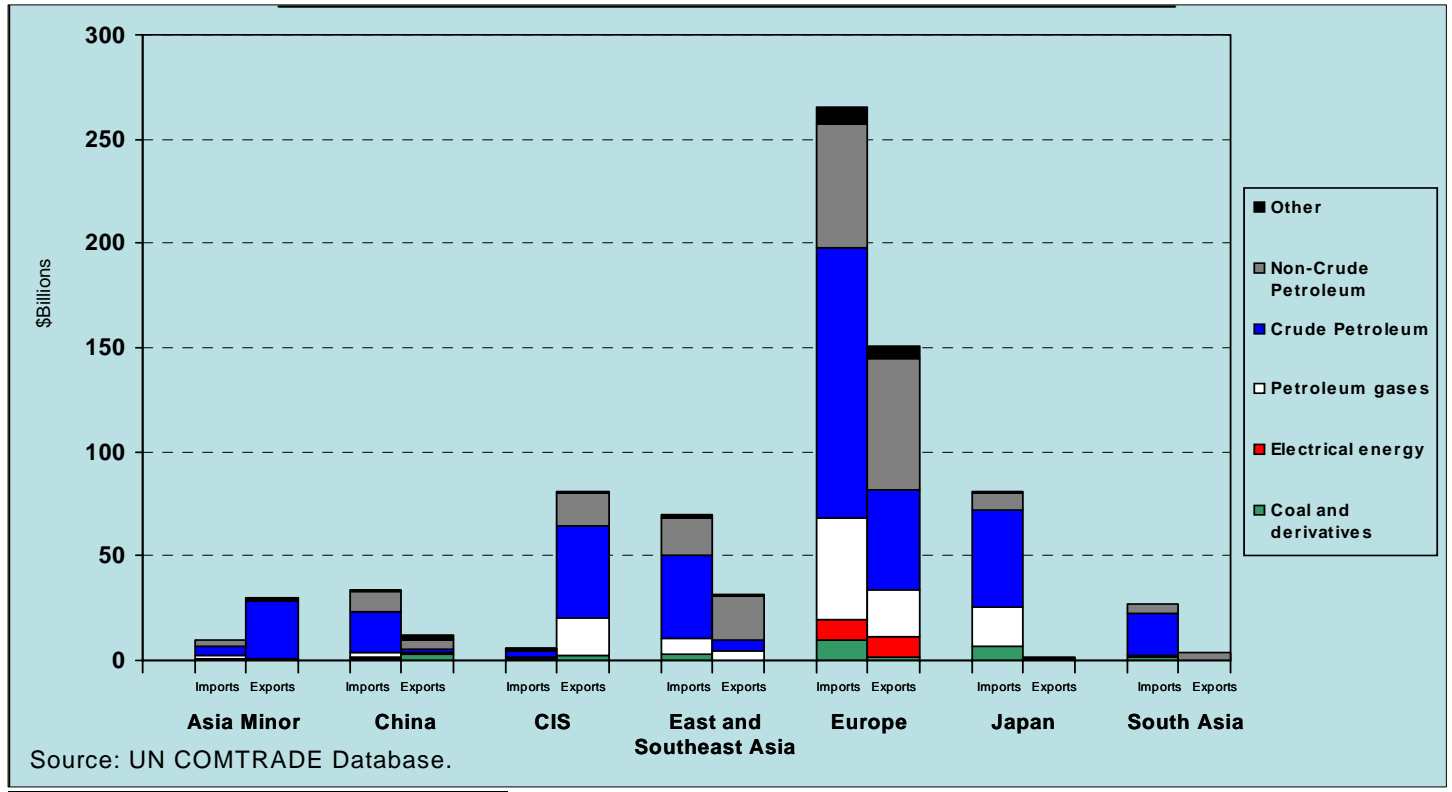

${ }^{7}$ Peter Thomson (2005) predicts that between 2003 and 2010 oil exports for Russia could increase by 130 million tons and from Azerbaijan and Kazakhstan by a total of 90 million tons. Of course, a lot depends on the implementation of energy development projects throughout CIS, often financed and managed by European interests. For example, the Karachaganak oil fields in Kazakhstan - which in early 2004 produced 210,000 bbl per day - are being developed by a consortium led by British Gas and ENI (Italy). By 2010 the Karachaganak oil fields should yield 500,000 bbl per day (EIA 2004d). 
Figure 4: Major Global Oil Trade Movements, (millions tons)

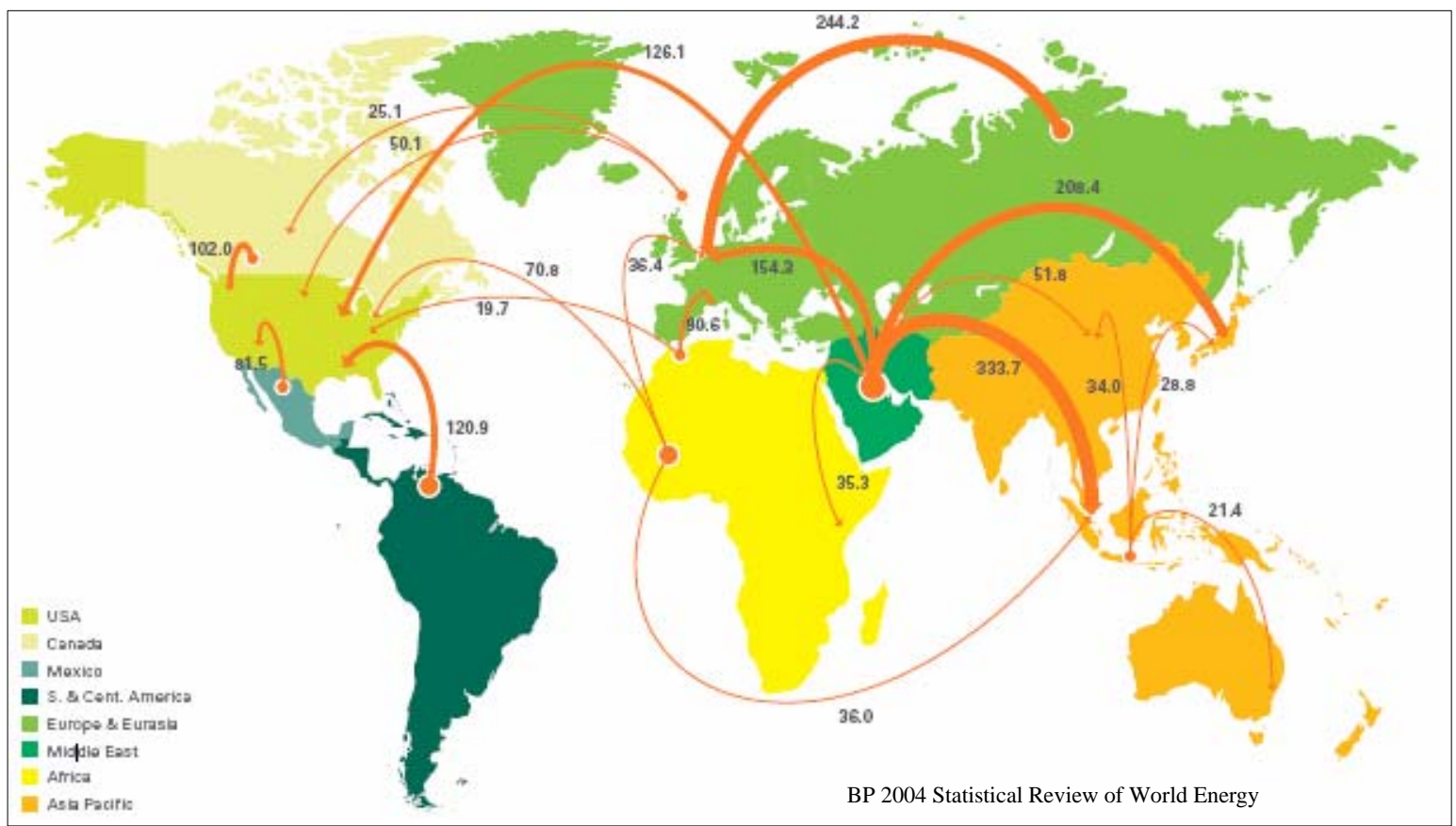

Figure 5: Major Global Gas Trade Movements, (billion cubic meters)

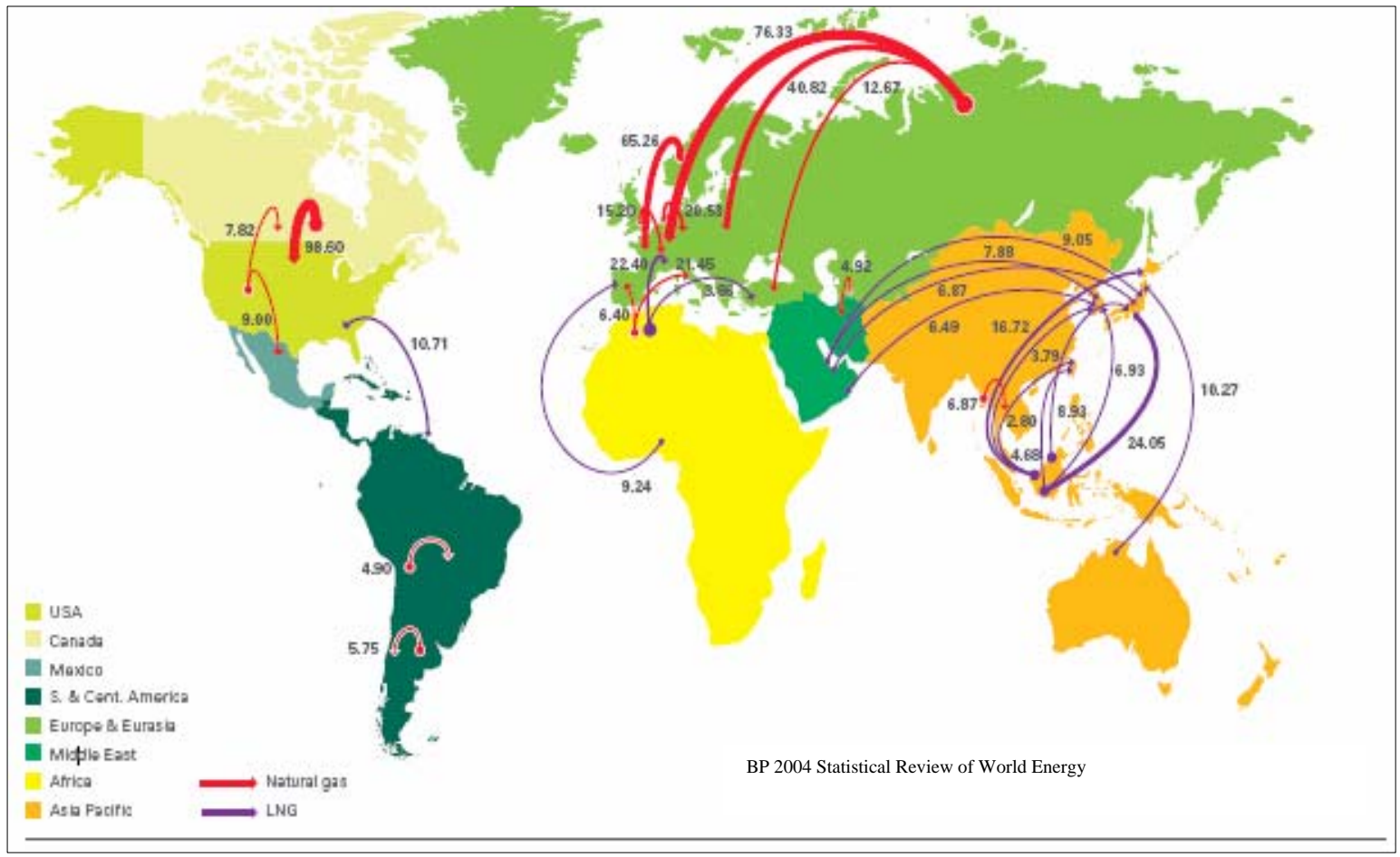


Data on energy trade within Eurasia show that there has been rapid integration among Eurasian sub-regions in recent years. Energy trade within Eurasian sub-regions grew at an average annual rate of 8.5\% from 1995 to 2003. During this period, energy trade between the different blocs grew annually by $14.6 \%$ (Figure 6 ). The blocs that are the most outward focused - measured by the relative weight of imports from outside the bloc - are China, Japan and South Asia. The former two satisfy their energy needs by importing from Eurasian countries, while most of South Asia's energy imports come from outside Eurasia.

\section{Figure 6: Energy Trade Within and Between Eurasian Regions}

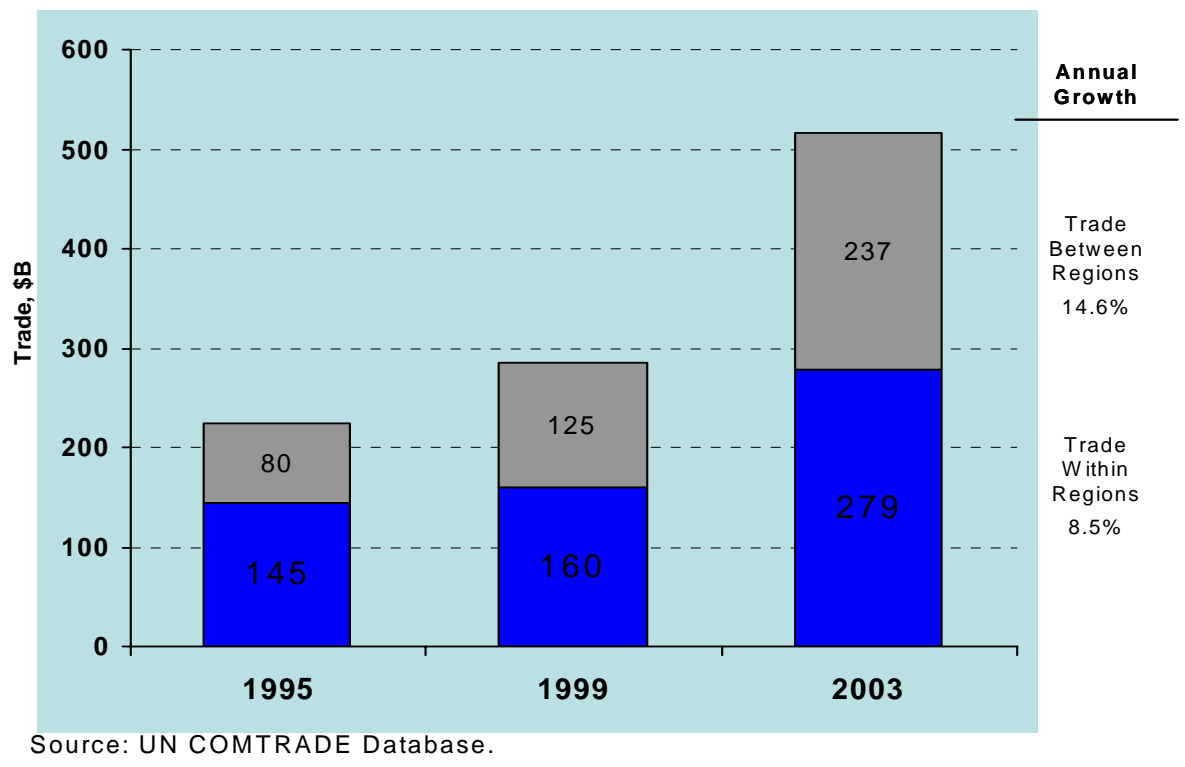

Bilateral energy trade remains largest internally within Europe, but is growing fastest between CIS and Europe and between Asia Minor and Japan. Growth is slowest within East and Southeast Asia and between it and its Eurasian trading partners. In sum, the data on regional energy trade in Eurasia show growing spatial integration.

To meet the burgeoning demand for energy in the region, resource rich areas - especially the CIS and parts of Asia Minor - have been expanding energy transport capabilities. For oil projects, new pipelines will either improve existing infrastructure and capacity for oil from Russia or will bring new sources of energy from the Caspian Sea region via Turkey. Natural gas pipeline networks, already considerably more dense than oil networks, will see expansion in much the same way: from Russia or from the Caspian region.

The reorientation of Eurasia's energy trade from a north-south (Russia-Central Asia) pipeline system from Soviet times into an East-West network extending into Europe and East Asia is still underway. There are a number of large pipeline construction projects, many of which involve Russian production and exports (see Figure 7), but there are currently also three large pipeline projects connecting the Caspian Sea region to markets in Europe. First is the Caspian Pipeline Consortium Project which will connect Kazakhstan’s oil fields to the Russian Black Sea port of Novorossiysk. The Baku- 
Tibilisi-Ceyhan (BTC) pipeline, a 1,040 mile, \$2.9 billion project will connect oil fields in Azerbaijan to the Turkish port of Ceyhan. It is expected to become operational in late 2005. (EIA 2004b) Azerbaijan currently lacks any infrastructure to export its natural gas. The $\$ 1$ billion construction of the 550-mile Baku-Tibilisi-Erzurum or South Caucus Pipeline (SCP) will allow Azerbaijan to export 1.5 bcf of natural gas per day (EIA 2004a). ${ }^{8}$

\section{Figure 7: Major Russian Oil and Gas Pipelines and Projects}

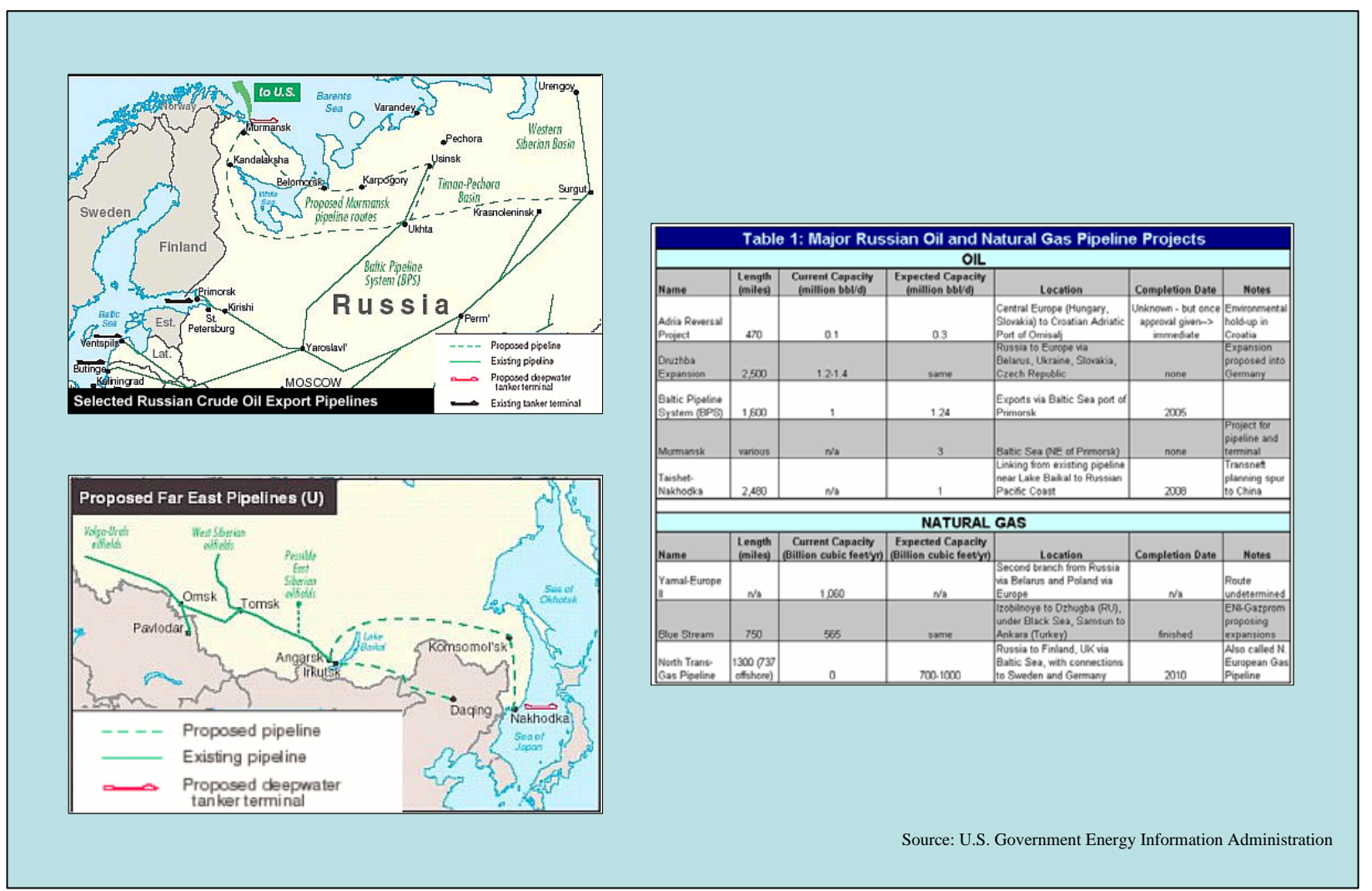

Source: EIA, 2004e

While pipeline construction feeding the European market has received the most attention, important projects have also been considered or are being undertaken connecting Russia and Central Asia to East and South Asia. ${ }^{9}$ For example, China and Kazakhstan signed a \$700 million contract in 2004 to construct a pipeline from Astasu to Xinjiang in Western China. Another pipeline into China, this one from Anagarsk in Russia, is being discussed.

\footnotetext{
${ }^{8}$ There is considerable economic and geopolitical interest in Europe and the US to diversify access to Caspian energy resources, as a way to avoid dependency on Russian exports and transit routes, especially for gas. See Cohen (2005), and Thomson (2005). In addition, the financial benefits to the transit countries can be substantial. Ukraine's revenues from gas transit amount to about $\$ 1.5$ billion a year. Georgia now receives $\$ 10$ million a year, which is expected to increase to $\$ 50$ million when the BTC pipeline is completed. Georgia's transit revenues will be further increased when the SPC gas pipeline is completed (Thomson 2005).

${ }^{9}$ With its completion in 1997, the Korpezhe-Kurt Kui pipeline, linking Turkmenistan and Iran, was the first Central Asian pipeline to bypass Russia. (EIA 2004b).
} 
If built it would carry as much as 1 million bbl per day (EIA 2004c). And in December 2004, Russia is reported to have "committed to building the Taishet-Nakhodka pipeline, a gargantuan 4,300 kilometer project that will cost $\$ 12$ billion and is designed to provide 80 million tons of oil per year to the Asia Pacific market, including 30 million tons to China.”(Cohen, 2005, p.2) In addition, India and Pakistan have a strong interest in Central Asian and Iranian gas, with options being explored for natural gas pipelines from Iran and Turkmenistan to Pakistan and India. (Blank, 2005) However, there are considerable political uncertainties that could impede such pipeline projects, especially continuing insecurity in Afghanistan. (Siddiqi, 2004)

In addition to a growing continental energy-interdependence for oil and gas, it is likely that there will be increasing integration of electricity grids for the continent. This will be driven in part by the efficiency benefits from integrated electricity grids and markets, and partly by the large long-term export potential of Central Asia for hydropower. In particular the Kyrgyz Republic and Tajikistan have large hydro resources which can in principle be exploited for electricity exports to the large neighboring countries and through "wheeling” across interconnected electricity grids even to distant markets in Europe and to Chinese and Indian population centers. (World Bank, 2004c; Thomson 2005). However, as the World Bank (2004) report on Central Asia's electricity export market potential makes clear (see also Figure 8), these are long-term development options, which will require large public and private investments. Such investments and their financing in turn will depend on firm take-off agreements and agreements on integrated electricity market management, on mitigation of political and security risks along transmission routes and on improvements in the domestic market regulation, operation and maintenance to ensure technically secure and commercially viable electricity market links (World Bank 2004, Thomson 2005). ${ }^{10}$

In sum, continued development and integration of the energy sector in Eurasia is a big opportunity and challenge. Eurasia's continued economic growth will depend to a significant extent on effective energy development. At the same time, with continued rapid increases in energy demand in major consumption centers, large investments in energy production and transport/transmission will be needed. Such investments will however only be made if there is a reasonably secure political, regulatory and investment climate in the region. The mutual dependence of key players in the energy sector will further increase over time, as will the potential for competition and even conflict among competing energy producers (Russia, Central Asia, Iran) and among energy consumers (the EU, China, India, Japan). And with Eurasia accounting for a large and growing share of both energy supply and demand in the world, the global energy demand and supply balance and hence global energy prices, and with it global economic growth, will increasingly depend on how Eurasia responds to its energy challenge and opportunity.

\footnotetext{
10 Through targeted engagements (equity participation, direct investments, supply and take-off agreements) Russia’s state-owned electricity company, RAO-UES, is positioning itself to play a major role in developing, managing and supplying the regional energy markets in and around the CIS. (Thomson 2005, Crane 2005)
} 
Figure 8: Central Asian Republics Power Development and Trade Strategy

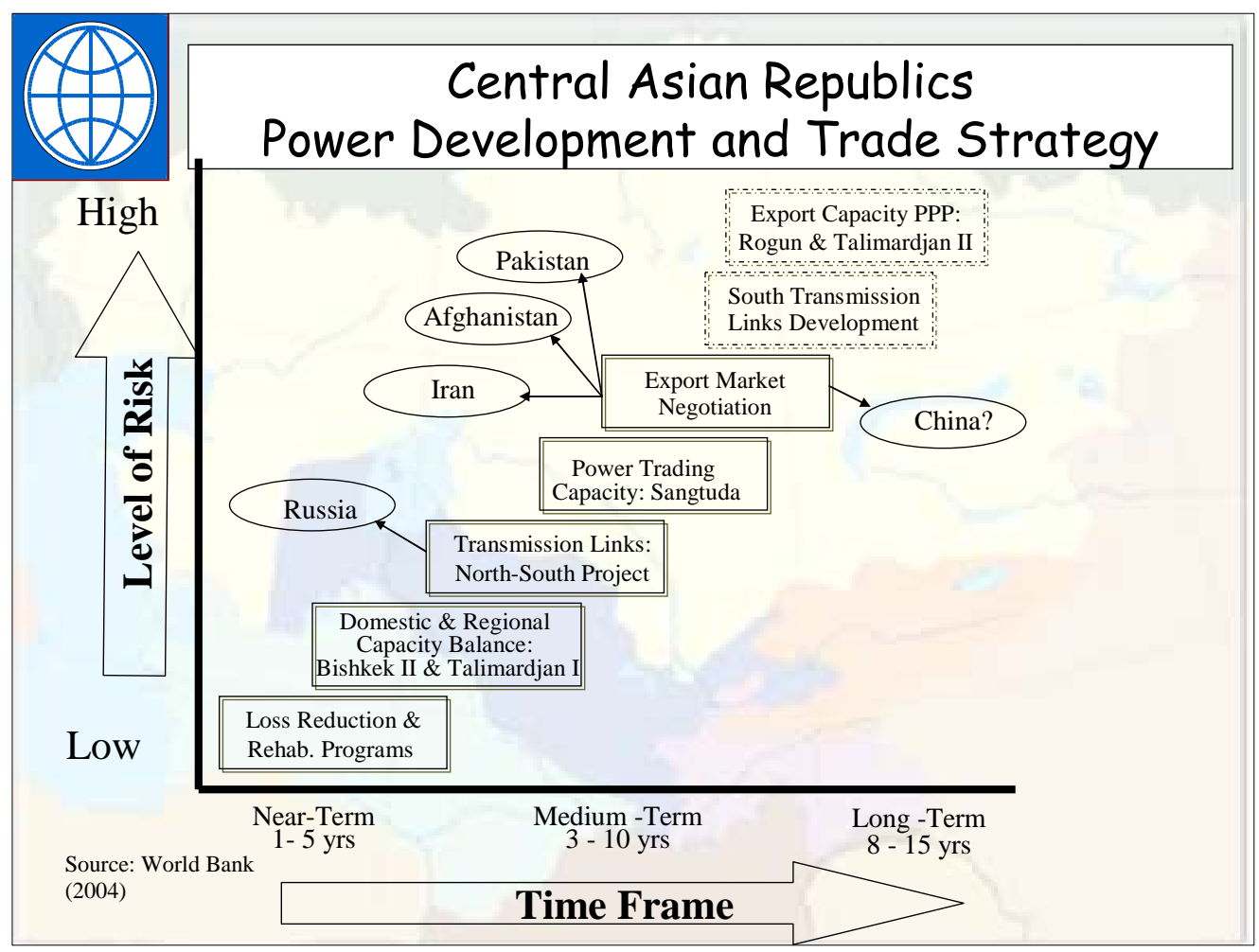

\section{Non-Energy Trade and Transport}

Traditionally, economic integration has been analyzed and measured mostly with regard to trade and transport linkages. Turning from the most obvious of such linkages in the area of energy to other areas, the first point to be made is that the collapse of the Former Soviet Union (FSU) had a devastating impact on trade within the former Soviet Union and its neighbors under the Soviet regional trading block known as COMECON. Of course, the trade that did take place prior to 1991 in the FSU was not the result market forces, but part of a highly specialized, regionally dispersed and highly integrated system of production and exchange under the Communist command economy. The collapse of much of this trade, along with other impacts of a far-reaching process of economic disintegration in the FSU, in turn caused a severe economic recession in the new republics of the FSU (Linn, 2004).

However, the collapse of the Soviet Union and of its highly integrated internal economic structure also opened the door for a far-reaching process of integration throughout the Eurasia region, by permitting for the first time in centuries the free flow of goods and services across the entire Eurasian super-continent. Not only did trade within the FSU recover, especially after the Russian financial crisis of 1998, but trade of the new FSU republics with the rest of the world and especially their neighbors in the Eurasian economic space also expanded rapidly as part of a growing regional trade integration process. Nonetheless, major obstacles still exist to the free and efficient flow of trade in 
the region: trade policies, transport infrastructure and transit conditions remain very problematic in many parts of Eurasia. They raise the costs of trade and severely reduce the competitiveness especially of the land-locked areas of the region. This section reviews the trends in regional trade of Eurasia and considers some of the opportunities and obstacles for further trade integration.

Three principal trading blocs make up the region - a European bloc, a CIS bloc and an Asian bloc. The trade data show that much of Eurasian trade takes place within trading blocs, while that trade between the combined Europe-CIS trading bloc and Asia exceeds that of each of these two blocs with the US. (World Bank, 2005) In other words, Eurasia is more connected internally through trade than it is with the rest of the world.

This picture can be refined by looking at the level, growth and composition of trade by sub-regional trading blocs within Eurasia (Figures 9-11). The following stylized facts emerge:

- For all sub-regional blocs, except Europe, trade with partners outside the subregion is more important than trade within the region. For example, CIS countries exported around $\$ 23$ billion worth of merchandise to other CIS countries, but exported $\$ 83$ billion to other Eurasian countries. ${ }^{11}$ Similarly, South and Southeast Asian countries traded $\$ 136$ billion worth of merchandise among each other, but \$304 billion with others.

- Second, for all sub-regional trading blocs, intra-Eurasian trade is more important, and in most cases much more important, than trade with the rest of the World. Even in the two most outwardly-focused blocs, Japan and South Asia, exports to non-Eurasian countries makes up only $43 \%$ and $46 \%$ of total exports respectively. Europe, the largest Eurasian trading bloc, sells only 20\% of its total exports outside of Eurasia.

- Third, overall export growth has been most rapid for Asia (excepting Japan), and it has been especially rapid in terms of the growth of exports from Asia to the rest of Eurasia. By contrast, the growth of Europe's and Japan's trade has been relatively slow overall and also within Eurasia. Much of the impetus for trade integration in Eurasia clearly emanates from and is associated with the rapid growth of much Asia (except Japan).

- Finally, despite the importance of energy flows in the region, trade is overwhelmingly concentrated in traditional non-energy areas, such as machinery and transport equipment (43\%), manufactured goods (30\%) and chemicals and related industrial products (13\%).

\footnotetext{
${ }^{11}$ Despite their recent recovery with regard to GDP and trade, CIS countries still under-perform in terms of export levels when compared to other countries of similar per capita GDP (Freinkman 2004).
} 


\section{Figure 9}

Eurasian Export Split by Trading Bloc, 2003

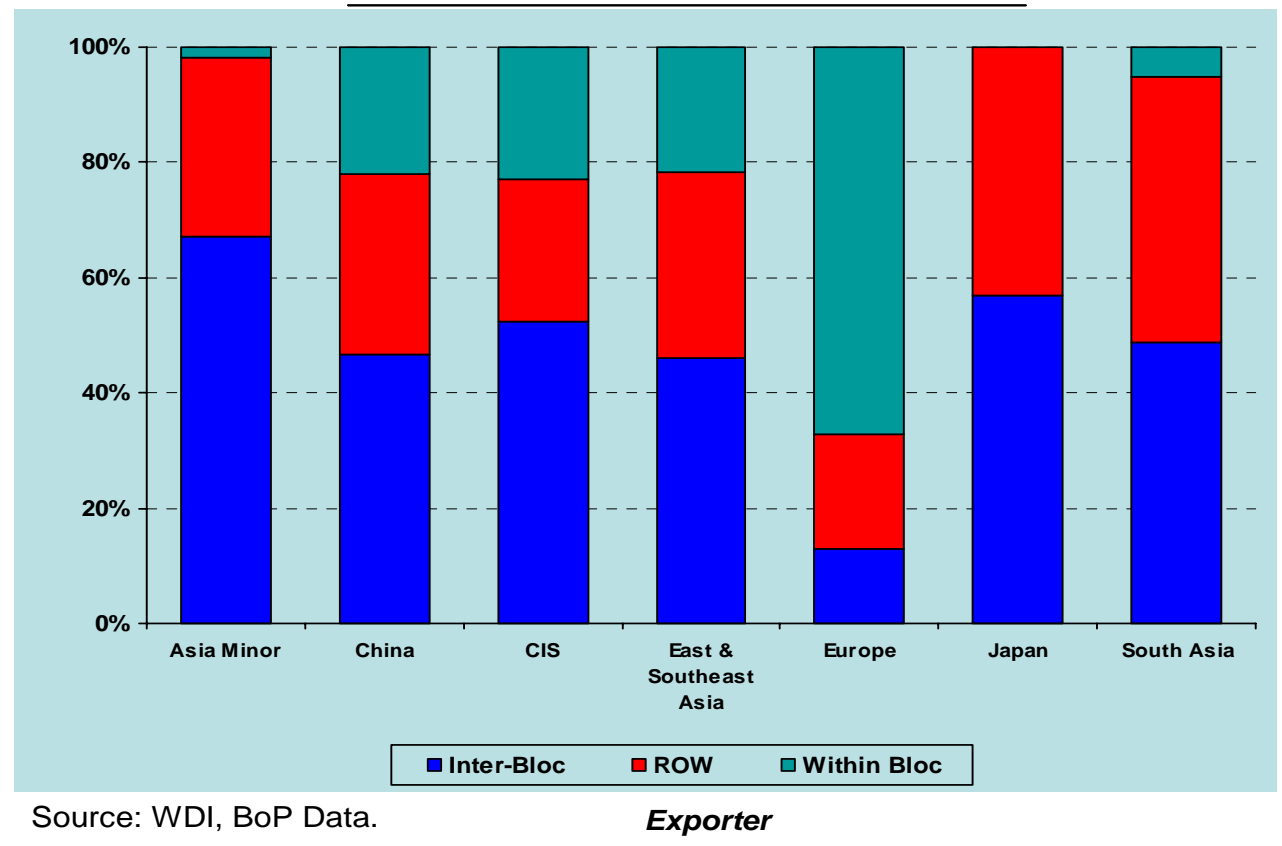

Figure 10

Growth in Exports of Goods and Services (By Region, 1992-2002)

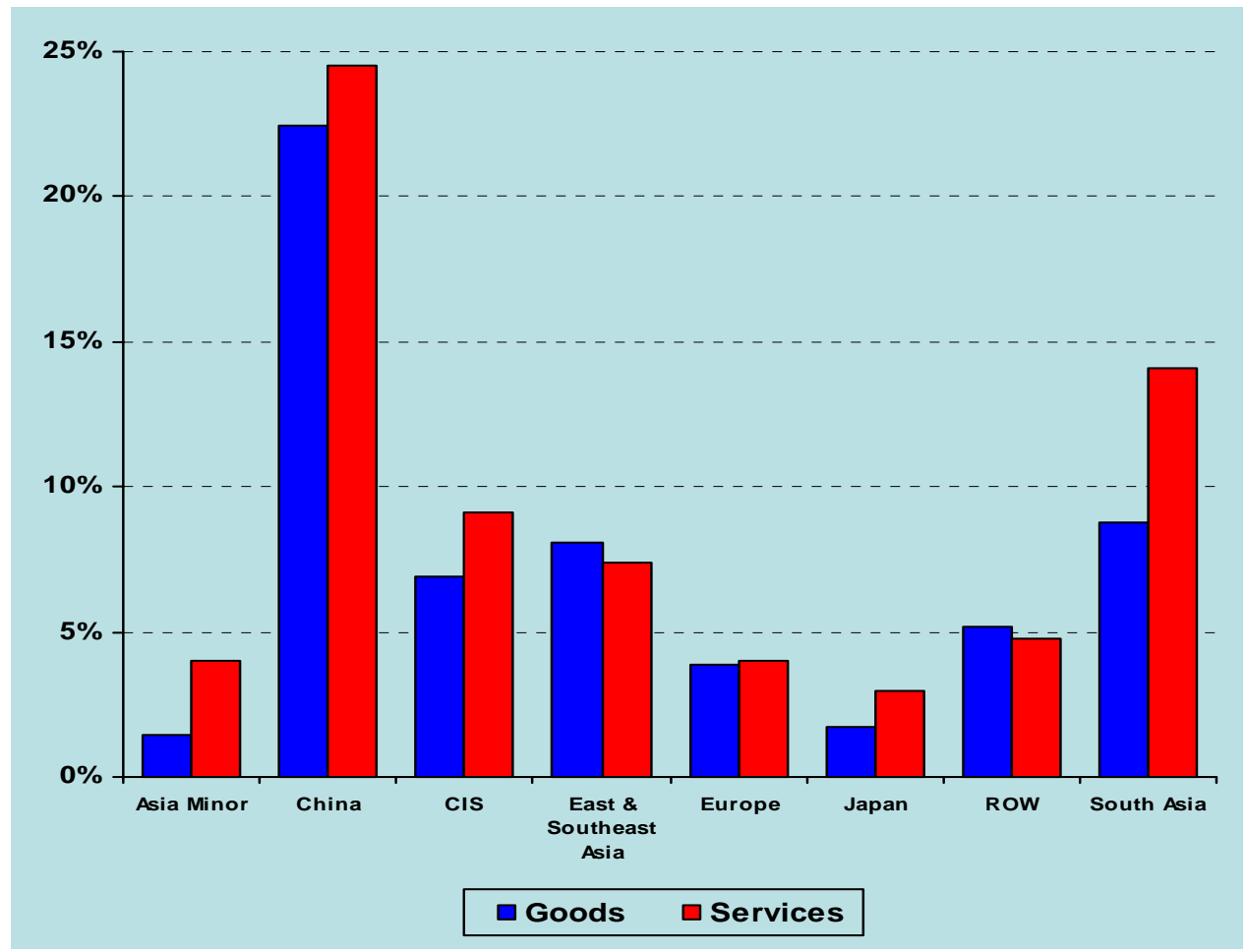

Note: CIS growth figures 1994-2002.

Source: WDI, BoP Data. 


\section{Figure 11}

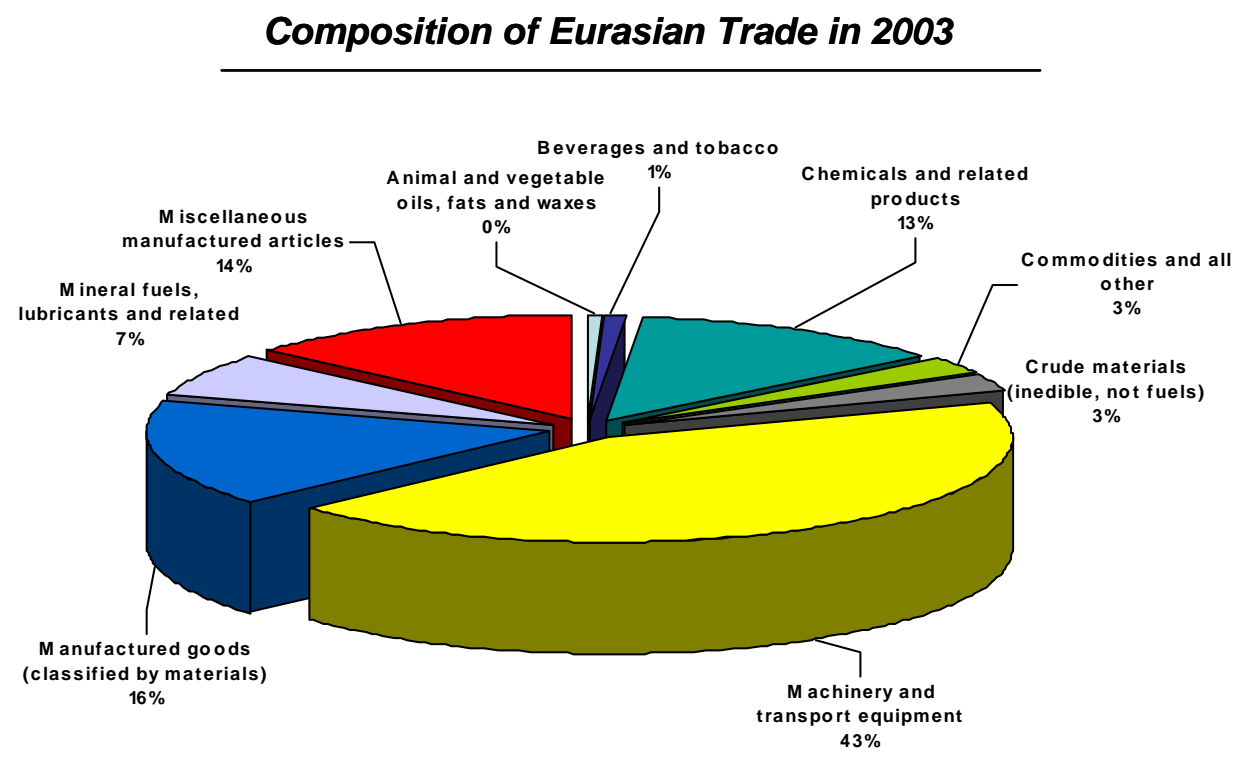

Source: UN COMTRADE Database.

Further trade integration in Eurasia will depend on three main factors: first, trade policy of the countries in the region; second, development of regional transport infrastructure; and third, transit and trade facilitation across and behind borders.

For trade policy, WTO membership is a key element of global and regional integration. China's membership in December 2001 was a major step forward in this regard, but since most CIS countries are not yet WTO members, their integration into the world economy and in Eurasia still lacks for now an important impetus. The largest of the CIS countries, Kazakhstan, Russia and Ukraine are expected to become WTO members in 2006 or soon after. This will be a major stimulus of regional trade integration.

Trade integration can also be pursued on a purely regional or bilateral basis. Here Eurasia shows some of the most intense activity around the globe with the frequency of regional trade agreements (RTAs) most significant in Europe and the CIS, although East Asia have engaged in many fewer such agreements (see Figure 12 and World Trade Organization, 2000).

The CIS countries, because of their central location at the heart of the Eurasia region, are particularly important for permitting and facilitating regional trade integration Eurasiawide. Various reviews of regional trade policy and agreements in the CIS (Akiner, 2001; Muzafarov, 2001; Freinkman et al., 2004; World Bank, 2005) have shown that the high frequency of bilateral, regional and global trade agreements in the CIS, while in principle to be welcome as a recognition of the importance of regional trade integration, in practice has not yet led to effective trade cooperation within the CIS. The principal reasons are 
two-fold: One reason is the complexity of the overlapping trade agreements, which leads to what is referred to as a "spaghetti bowl" effect of confusing and often unimplementable trade relations among countries in the region. The second, and related, reason is that most of the agreements have actually not been implemented or enforced in practice, either due to a lack of political readiness for cooperation and integration, or because of the weakness of administrative capacity and high incidence of corruption in implementing national trade policies in many of the CIS countries.

Figure 12. Regional Trade Agreements (RTAs) Globally

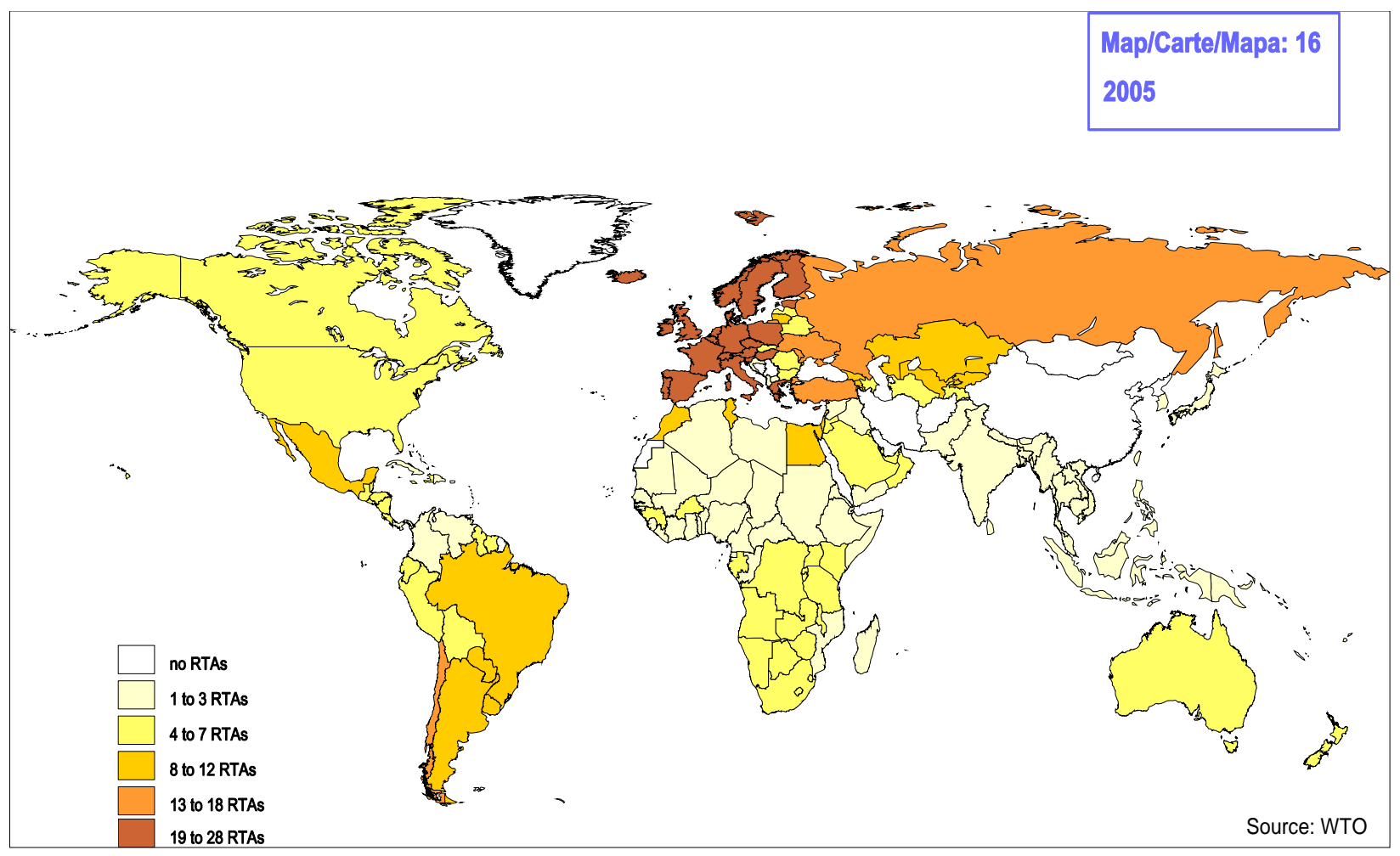

Aside from trade policy, transport infrastructure and transit facilitation are key elements that determine the costs of trading and access to world markets. These are particularly significant for the vast land-locked regions of Eurasia, most notably the countries of Central Asia. The distances to the nearest ports and some estimated costs of shipping (both in terms of money and time) are summarized in Figure 13.

The key question which confronts governments and private firms alike in Eurasia is whether and how the costs of shipping over the land routes can be significantly reduced in the foreseeable future. One element is the improvement in the transport infrastructure (rail, roads and air). Various elements of this are being put in place in various parts of Eurasia: From the West, the Trans-European Network (TEN) and the Transport Corridor Europe Caucasus Asia (TRACECA) programs of the European Union have made efforts to strengthen transcontinental transport routes. From the East, the Asian Development Bank has supported regional transport infrastructure improvements in Central Asia and 
Western China (in cooperation with other international financial institutions and the countries of the sub-region under the umbrella of the Central Asia Regional Economic Cooperation Initiative - CAREC). And Kazakhstan has announced that it "will start building a railway link in 2005 connecting East Asia with Europe.” (Kazakhstan 2004). Since 2002, with the opening up of Afghanistan and the rehabilitation of the Afghan road net work and reconstruction of key bridges between Afghanistan and its Central Asian neighbors, the north-south transport corridor in Central Asia is being reopened. Plans are also being made for improved regional transport interconnection in North-East Asia (NIRA, 2003). In view of the great distances in Eurasia, the scope for the expansion of air transport is also huge. At this time, some parts of Eurasia, in particular the South Caucasus and Central Asia, are very poorly served by international and regional air service, although some investments have been made modernizing regional airport facilities with donor assistance.

Figure 13: Transit Links of Central Asian Republics with World Markets

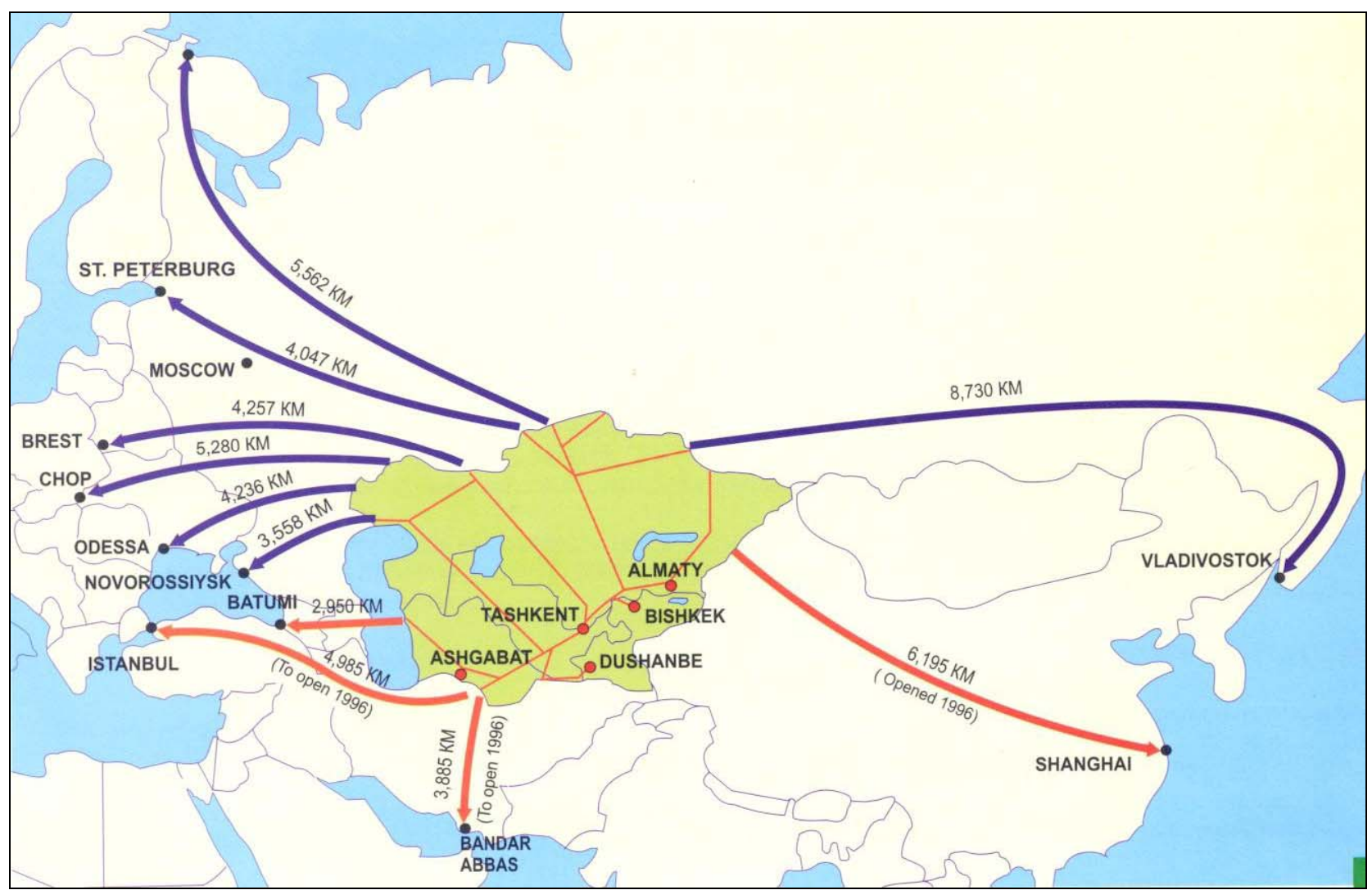

Source: UNESCAP, 2003.

Perhaps the greatest challenge to further trade integration lies in the need for improved transit facilitation across the many boundaries and long distances involved in the transcontinental transport routes of Eurasia. In some ways problems have been getting worse rather than better: 
- increased visa requirements (e.g., among CIS member countries, but also in Central Europe with the expansion of the European Union ${ }^{12}$ ),

- time consuming customs and other border inspections and expensive fees,

- informal and corrupt payments required at border and interior check points and police barricades, ${ }^{13}$

- limited coverage and high expenses of the TIR (International Convention for Road Transport in Transit Traffic) system,

- high Russian fees for over-flight rights for trans-Siberian international flights; ${ }^{14}$

- lack of communication between border posts on transcontinental routes;

- lack of, or poorly developed, private trade-forwarding institutions in many of the CIS countries.

Various initiatives are underway on a sub-regional basis to improve transit facilitation in key Eurasian corridors. For example, the Trade and Transport Facilitation in South East Europe Program (TTFSE) is designed to reduce dramatically the time it takes to cross the many borders as trucks move from Turkey to Western Europe while actually improving customs and security controls. ${ }^{15}$ For Central Asia the EU Border Management Program for Central Asia (BOMCA) is designed to help improve border management. ${ }^{16}$ But much needs to be done to improve transit conditions so as to facilitate an expanded flow of trade throughout the Eurasian region.

In sum, there is already a significant amount of intra-regional trade across the Eurasian super-continent, but further trade expansion is possible and likely, especially if it is supported by improved trade policy (especially WTO access by the larger CIS countries), improved transport infrastructure, and enhanced trade facilitation. More work is needed to assess the likely investment requirements, the key priorities and sequencing of measures, and to estimate the possible gains from improved integration. In addition, improved cooperation among the governments of the countries in the Eurasia region and in key sub-regions will be essential to make sure major remaining obstacles to increased trade integration are removed or at least mitigated. ${ }^{17}$

\footnotetext{
${ }^{12}$ The EU required its new member countries, among them Poland and Hungary, to tighten visa and other entry requirements for border transit with their eastern neighbors (Oxford Analytica 2005).

${ }^{13}$ This can cost around \$1,500 per truck for crossing one country alone (Kazakhstan) (EBRD 2003). When moving a generic consignment from Northern Europe to Tbilisi, Georgia the Georgian leg of the journey accounts for almost half of the total transportation costs. It is estimated that $90 \%$ of the costs incurred in Georgia accrue to border guards, road police and other such agencies (World Bank 2003).

${ }^{14}$ According to a report in the Financial Times (March 15, 2005) European carriers paid Aeroflot, the Russian state airline, $€ 250$ million in 2003 for the rights to fly over Siberia.

${ }^{15}$ This program is financed by the World Bank. See the official website http://www.ttfse.org/ .

${ }^{16}$ This program is financed by the European Union and implemented by UNDP. See the official website www.eu-bomca.org/en .

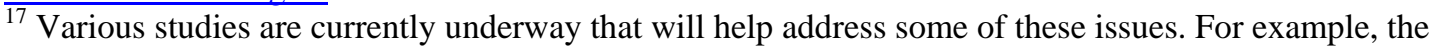
World Bank is carrying out a major study on integration of the Europe and Central Asia Region. UNDP and ADB are collaborating on a study of regional integration and cooperation in Central Asia which among other things aims to estimate the benefits to Central Asian countries from enhanced trade, transport and trade facilitation. However, while extremely useful pieces of the puzzle, even these studies remain partial in their coverage of the Eurasian integration process.
} 


\section{Trade in Illicit Drugs}

One more flow of trade is of special significance for the Eurasia region: the trade in illicit drugs. ${ }^{18}$ Eurasia has an overwhelming share of the world's intravenous drug users (IDUs) accounting for some $75 \%$ of the total and Eurasia's drug problem is principally one involving the use of opiates and its production. Over $60 \%$ of the world's illicit drug use involving opiates takes place in Eurasia, and well over $90 \%$ of the world's opiate production located in three countries of Eurasia - Afghanistan, Lao PDR and Myanmar/Burma. Afghanistan alone produces an estimated three-quarter of the world's opium.

The principal flows of drugs in Eurasia are shown schematically in Figure 14. Exact quantification is difficult, but it is clear that the illicit drug trade moves huge quantities of opiates across Eurasia. Although production of opium in the "Golden Triangle" of South East Asia appears to have somewhat declined in recent years, by all accounts, production in Afghanistan in 2003 and 2004 has reached near record levels. (Neuberg, 2005) The potential farm gate value of global opium production was estimated by UNODC to amount to about $\$ 1.2$ billion in 2003. In recent years opiate use appears to have stabilized and may even be declining in Western Europe, but has been increasing rapidly in Russia, which, according to UN estimates, is now the largest heroin market in Europe. In Asia, too, a stabilizing trend in drug use can be discerned, with the exception of China, where drug use appears to have increased at least through 2003. During that year the estimated number of drug users in China was in excess of one million, representing a 15fold increase since 1990. An increasing share of the drug trafficking from Afghanistan appears to run through Central Asia. According to one estimate there has been a 30-fold increase in heroin seizures in Central Asia since 1993. (Osomanliev, 2005)

\section{Figure 14: Drug Flows in Central Asia}

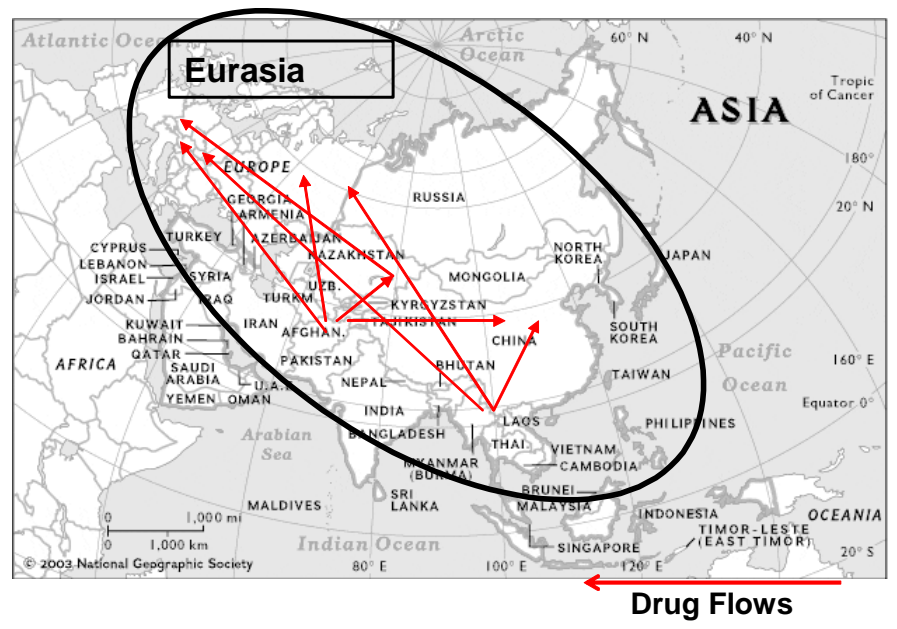

\footnotetext{
${ }^{18}$ Unless otherwise noted the information and data provided this section are drawn from United Nations Office on Drugs and Crime (UNODC), 2004
} 
Many efforts have been and are being made to control the production, use and trafficking of drugs in the countries and sub-regions of Eurasia, but they have had little impact on the flow of illicit drugs across the super-continent. (Swanstrom, 2005; Cornell, 2005) Like elsewhere in the world, as long as high demand for illicit drugs continues to persist in Western Europe, Russia and increasingly in China, it will be impossible to reduce significantly the production in places like Afghanistan. Equally, it will be impossible to stop the trafficking of drugs through standard transit routes, such as Central Asia. Unfortunately, this trafficking in drugs has a very corrosive impact on the transit countries, as the illegal flow of drugs undermines already weak governments, fosters corruption and crime, and locally also leads to increased drug use and with it increased risks of drug-related diseases, especially of HIV/AIDS. A concerted approach to the region-wide drug problem for the Eurasian super-continent therefore is an increasingly pressing priority. Certainly, as long as the principal hubs of drug consumption do not control the demand for drugs, measures to limit production and transcontinental trafficking will have no real effect.

\section{Investment and Capital Flows}

Cross-border investment and capital flows, particularly foreign direct investment, have also become a force for integration in Eurasia. Until about two decades ago, there was almost no FDI or other capital flows to speak of in the region, except in Western Europe, Japan and South-East Asia. China and India had yet to start the process of liberalizing their economies and the former Soviet Union with its command economy and isolationist economic policies was still intact. The opening up of China and fall of the Soviet Union, and the resulting reorientation of political alignments and trading patterns in Eurasia have been accompanied by a surge in foreign direct investment in the region outside the traditional areas. While Europe is still the largest recipient and source of FDI, investment growth is fastest east of Europe.

FDI and capital flows contribute to integration via two channels. First is the obvious channel: capital flows from one country to another create direct economic ties. Secondly, by promoting growth and technology diffusion, capital flows increase trade and economic cooperation - through which integration is further enhanced. But there are also significant potential downside risks from financial and capital market linkages:

- The potential contagion effect of one country's financial crisis on neighboring countries is perhaps the most obvious. This was painfully obvious in 1997/8, when the financial crisis which started in East and South East Asia has worldwide repercussions, and also affected Eurasia. For example, the withdrawal of Korean investors from the Russian government bond market in the wake of the Korean financial crises was one factor explaining the timing of the Russian financial crisis in 1998. The Russian crisis in turn affected Russia's neighbors through reduced trade and investments.

- Another downside of capital mobility is capital flight, For example, some \$20 billion of flight capital a year are thought to have left Russia during much of the 1990s. Much of it likely found its first "resting place” in Western Europe (especially Cyprus and Switzerland). 
- Finally, there is the monetary dimension of international financial linkages: Asian central banks have held large international foreign reserves, mostly in US dollars. However, with the introduction of the Euro and the depreciation of the dollar in recent years, there has been speculation that Asian central banks may wish to diversify their reserves by increasing their Euro holdings relative to the dollar. The difficulties which the EU encountered in mid-2005 in ratifying its new constitution may have weakened such tendencies for the immediate future.

In the rest of this section we shall focus mostly on foreign direct investment (FDI) as an important source of economic linkage and integration. Unfortunately the data on FDI are weak, especially since they do not readily permit an assessment of regional and subregional FDI numbers and trends disaggregated by destination and source. Nonetheless, we have taken a first stab at the available numbers to see whether the stylized FDI flows shown in Figure 15 are broadly accurate.

\section{Figure 15: Eurasian Capital Flows}

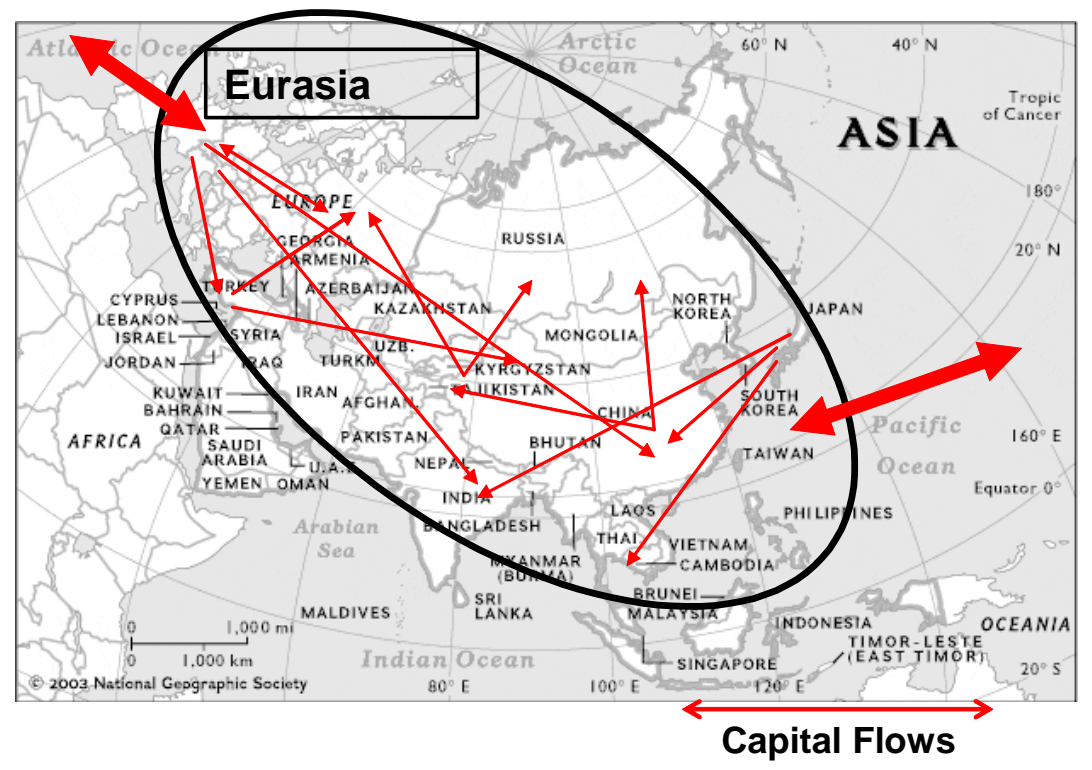

Eurasia as a whole is a net foreign direct investor, albeit only slightly so. It is the repository of over 60 percent of the world's FDI stock (Figure 16). Within Eurasia, Europe is both the biggest investor and recipient of investment. Europe, China and East and Southeast Asia together account for almost the entire stock of FDI. Investment volumes in CIS, Asia Minor and South Asia are negligible by comparison, but interestingly these three regions are also the ones that have seen the greatest FDI growth from 1995 to 2003. For example, while FDI growth in Europe has averaged around 15\% annually (for both inward and outward investments from 1995-2003), annual inward and outward FDI growth has been $31 \%$ and $43 \%$, respectively, for the CIS. For South Asia, FDI growth rates have been $17 \%$ and $30 \%$ (Figure 17). In part this reflects growth from a low base. 
Figure 16: Global and Eurasian FDI Stocks, 2003

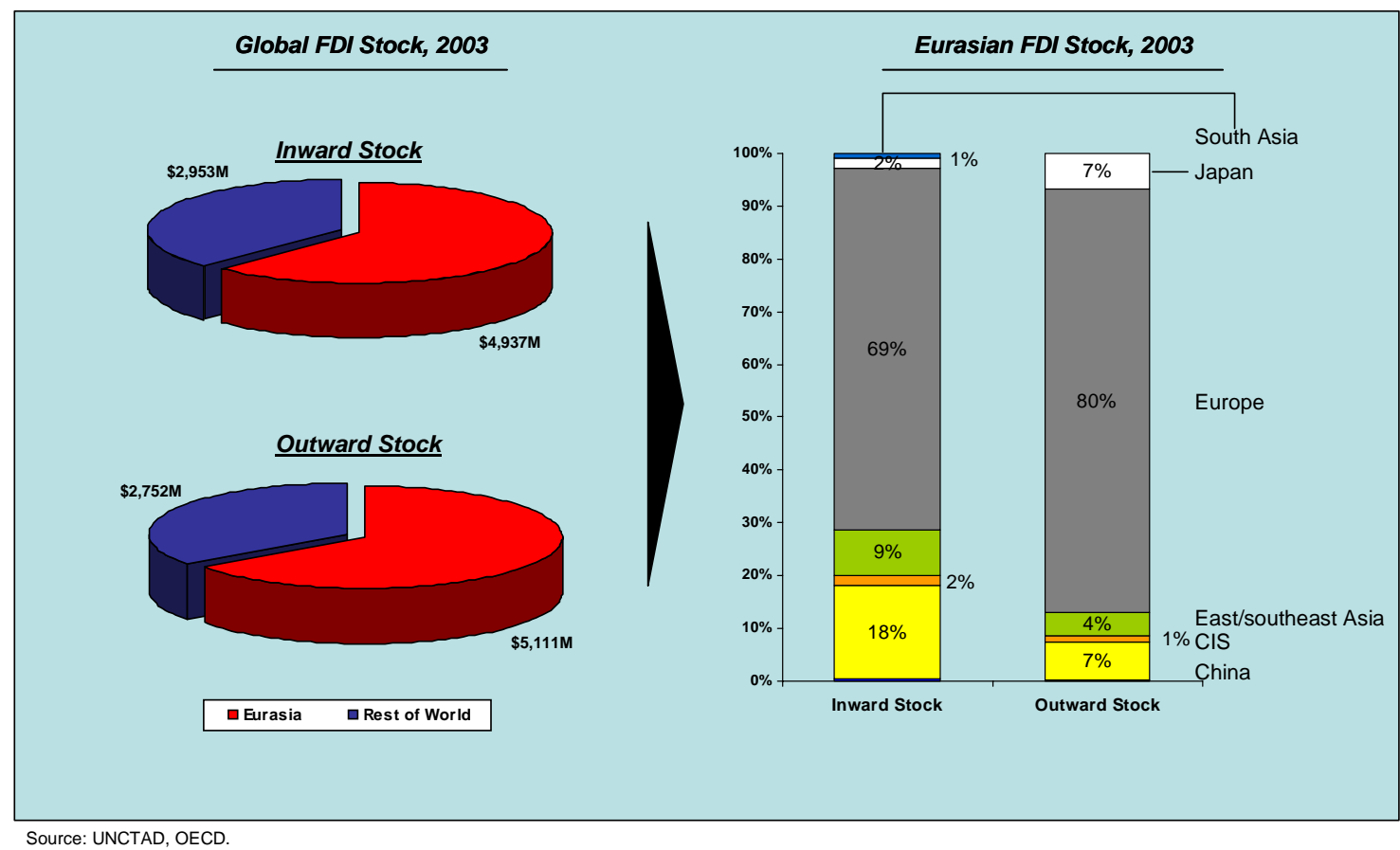

Source: UNCTAD, OECD.

Figure 17: Growth of the FDI Stock by Region, 1995-2003

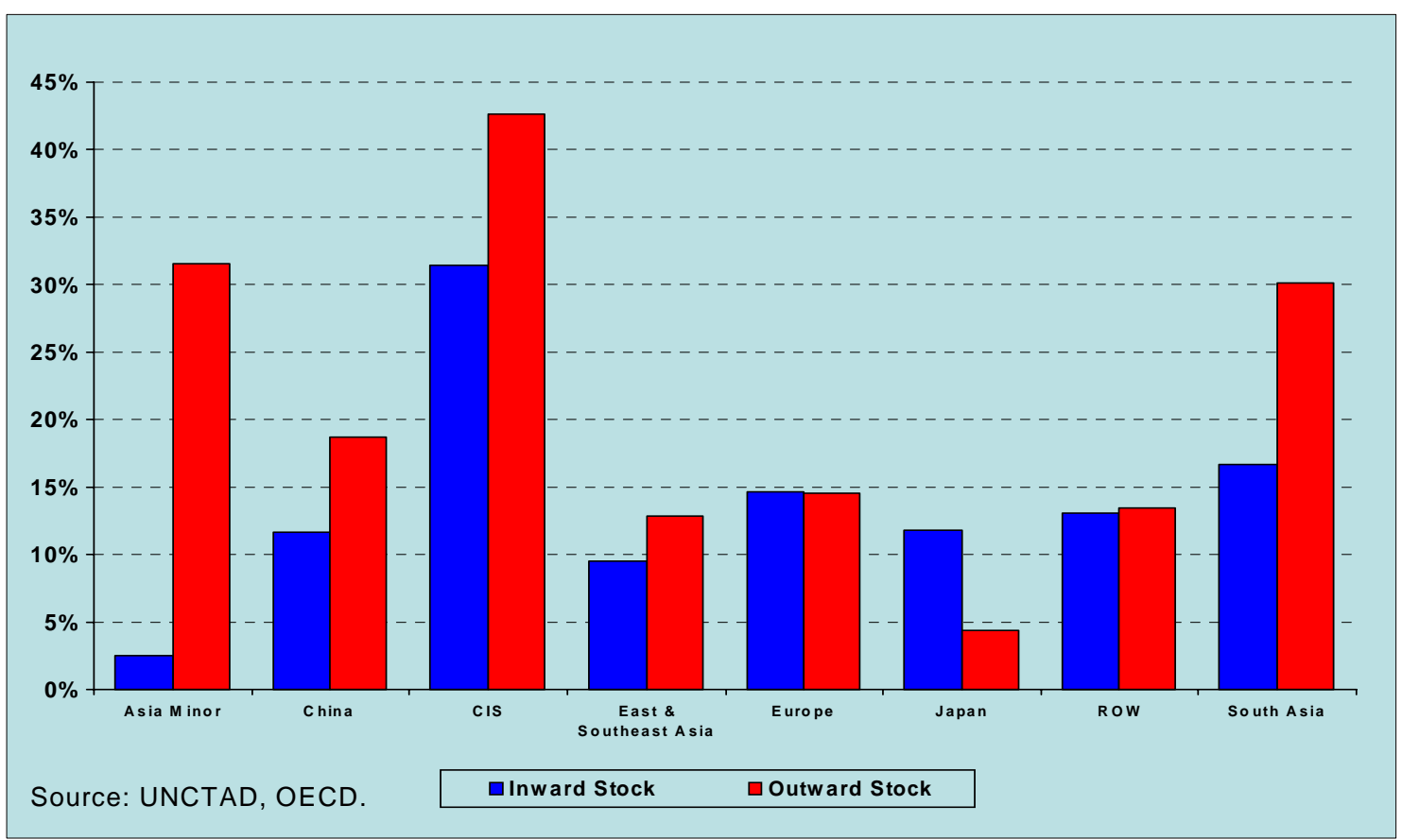


We can derive a number of broad conclusions regarding the composition and direction of FDI trends for Eurasia. Traditionally, FDI flows from the EU and Japan to the rest of Eurasia have been the most significant, albeit relatively small compared to the two-way FDI flows from and to the rest of the world (especially the US). Nonetheless, some new trends have emerged recently, which point to increased regional integration and diversification of capital flows within Eurasia. First, over the last 20 years there has been a rapid increase of European investment in China and since 1998, there has been increased direct investment from Europe to Russia. Second, recently, significant investment flows have also emerged from Russia to Central and Western Europe and to the rest of the CIS. ${ }^{19}$ Third, there has been increased FDI from Turkey in the CIS, especially in Russia and in Central Asia. And finally, China and India have started investing in the CIS, especially in the energy sector, as part of their strategy to increase their access to Russian oil. ${ }^{20}$

This increased FDI engagement across borders in Eurasia is to be welcomed for a number of reasons: First, all available evidence, including research in the region itself, confirms that foreign direct investment on balance helps improve productivity and growth. For example, Carstensen (2004) has used panel level data to examine the welfare effects of FDI in Central and Eastern Europe, and finds the link between FDI and growth to be significant. And Campos (2002) examined the impact of FDI on GDP growth based on panel data on 25 countries in East and Central Europe and the former Soviet Union between 1990 and 1998. He finds that FDI has a positive and significant causal impact on GDP growth. These findings imply that FDI - via the channel of higher economic growth and the resulting growth in trade - has the externality of encouraging further integration, not only between the two countries which were involved in a particular investment transaction, but region-wide.

Of course, a major prerequisite for higher FDI, from other parts in Eurasia and from the rest of the world, in the lagging sub-regions (CIS, Indian subcontinent, Asia Minor) is that the local business and investment climate be supportive for investment and enterprise development more generally. Much remains to be done in this regard not only at the national level in these sub-regions, but also at the provincial and municipal level, since much research on success and failure to attract foreign investment has shown the importance of local business conditions. ${ }^{21}$

\footnotetext{
${ }^{19}$ Crane (2005) has looked at Russian investments in the CIS and found that Russian firms are indeed increasingly investing in neighboring CIS countries. Russia has a considerable share of FDI inflows in Belarus, Moldova, Armenia and Ukraine. Russian firms seem to be more adept than investors from Western industrialized countries in dealing with the poor business climate widely prevailing in the CIS countries. Crane also concludes that with the exception of the energy sector, the Russian government has not been directly involved in guiding foreign investments.

${ }^{20}$ Some observers are talking about the revival of the idea of a "Strategic Triangle" (attributed originally to former Russian Prime Minister Primakov) between China, India and Russia in the political, energy and commercial fields (Bajpaee, 2005; see also Cohen, 2005; Blank 2005; Mitra, 2005 for growing energy investment links between Russia with China and India.)

${ }^{21}$ See EBRD (2003) for the transition economies. For Vietnam, Meyer (2005) analyzes the importance of local institutions and policies - including local education rates, industrial real estate availability, and passenger transport volumes - in attracting foreign direct investors. He finds that such sub-national institutional factors have a significant impact on FDI entry location and mode. Elsewhere in China, case
} 
In conclusion, the recent growth of cross-border investments in Eurasia as part of the growing economic integration of the super-continent is welcome. Judging from the experience of economic integration in the EU, as well as across the Atlantic between the US and Europe and across the Pacific between the US and East Asia, in the longer term it is the integration of firms through investments across borders which brings the greatest boost to trade and growth, as well as the greatest guarantee of stable long-term political relations. $^{22}$

\section{Migration $^{23}$}

Population movements have been another important integrating factor in world history, including in Eurasia. Historically large transcontinental migration flows of people took place in prehistoric and ancient times - mostly from East to West. Then there was - in the opposite direction - significant voluntary and forced migration of Russians ${ }^{24}$ in Tsarist Russia, and subsequently the mostly forced movement of large numbers of people in the Soviet Union. More recently, Europe experienced large refugee flows as a result of wars during the $20^{\text {th }}$ century, and substantial migration post-World War II in response to economic opportunities. However, these migration flows within Eurasia do not compare in relative size or significance with the centuries-long history of transatlantic migration from Europe to the United States. ${ }^{25}$ As with trade and capital flows, the Iron and Bamboo Curtains - and especially the restrictive immigration policies in Europe - acted as effective barriers to large movements of people on a transcontinental scale.

After the demise of the Soviet Union, there were initially some sizeable movements of people mostly of Russian origin from the new CIS republics back to Russia. Hill and Gaddy (2003) cite estimates of around 3 million people. And in countries with war and civil disturbances, refugees and internally displaced people relocated often within their own countries (Azerbaijan, Georgia, and Tajikistan). Since the early transition years, however, most of the migration movements have been for economic reasons. They fall into several streams, as schematically shown in Figure $18:^{26}$

- Migration within the recently enlarged European Union and its immediate neighbors (esp. Turkey, South East Europe and Ukraine, Moldova, etc.).

studies have pointed out the importance of an active city government in reaching out to and attracting foreign investors (Wang 2004).

${ }^{22}$ For a discussion of the role of economic links as a glue for stable long-term transatlantic relations, see Linn (2004).

${ }^{23}$ Much of the information summarized in this section is gleaned from Hill (2004) and Hill and Gaddy (2003). A major study on migration in Europe and Central Asia is under preparation at the World Bank and, once completed, should throw considerably more light on the issues tentatively explored in this section.

${ }^{24}$ Some non-Russians from the West, such as German settlers, were invited to various parts of the Tsarist Russia and then further resettled, mostly in Central Asia, under Stalin (Janssen 1997). There was also settlement of significant numbers of non-Russian settlers from the East, especially Koreans in Central Asia (Diener 2004 ).

${ }^{25}$ There were also significant transpacific migration flows from Asia to the US (Min 2002).

${ }^{26}$ There are of course other migration flows not shown in Figure 17, particularly from Africa to Western Europe. 
- Migration from South Asia to Western Europe, often in stages, via the CIS; in frequent cases, such migrants stay considerable periods in transit or settle along the way in the CIS countries, due to difficulties entering Central and Western Europe.

- Migration from Central Asia to Russia (and increasingly within Central Asia to Kazakhstan).

- Migration within Russia from the cold northern and north-eastern regions to Central and South-Central Russia

- Migration within China and from China to Far-Eastern Russia.

\section{Figure 18: Migration Flows in Eurasia}

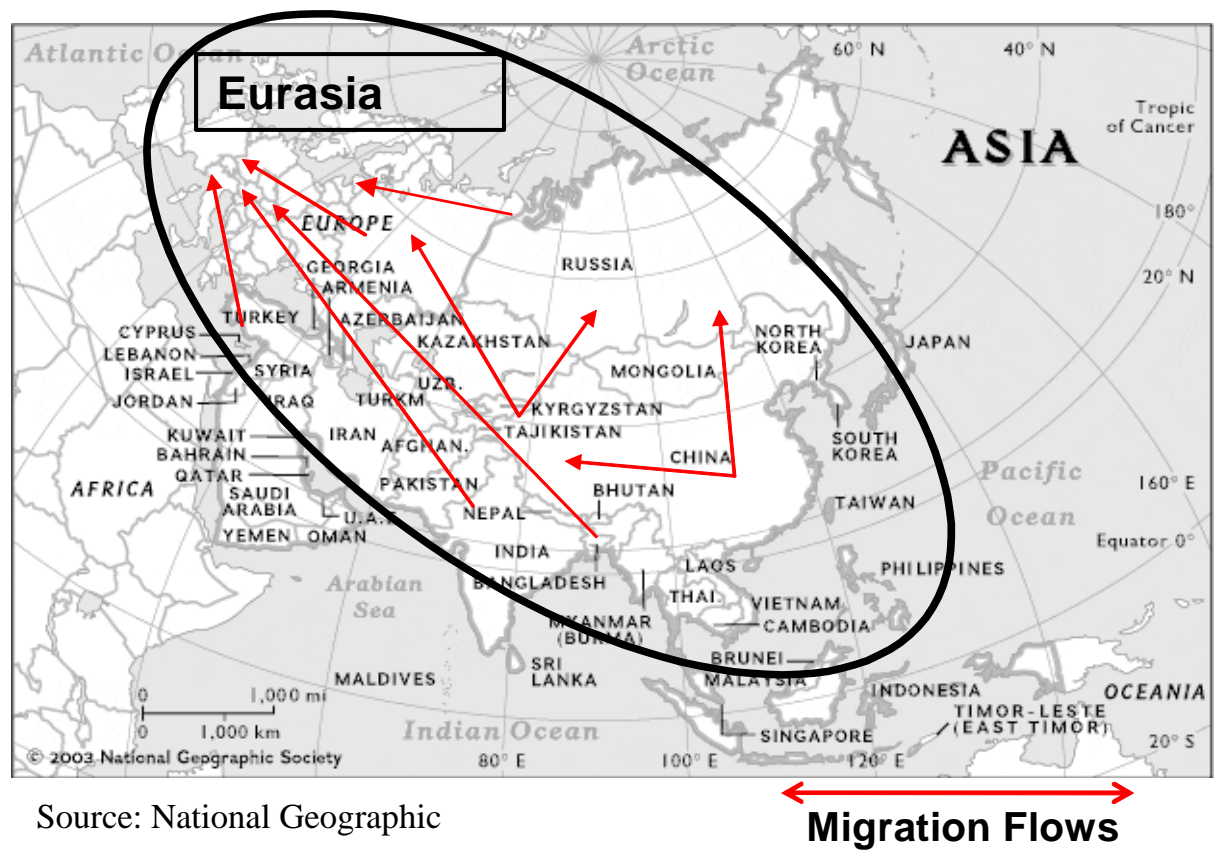

Unfortunately, comprehensive and accurate data on Eurasian migration flows are scant. It is hoped that ongoing research will help fill some of the gaps. From the information that is available (UN, 2002; OECD, 2002), it appears that none of these migration flows are currently very large in absolute or relative terms when measured by historical standards of major migration movements. However, there are exceptions for certain countries and locations both in terms of the countries of origin (for example, the cumulative migration to Russia from the Kyrgyz Republic and from Tajikistan has been estimated to represent almost $10 \%$ for Kyrgyzstan and up to 18\% for Tajikistan) (Irinnews, 2004) and in terms of certain locations of the receiving countries (certain parts of Moscow, for example, are heavily populated with Central Asian migrants, just as certain parts of Berlin house large concentrations of Turkish immigrants).

Looking ahead, one can project that there will be increasing pressures for larger transcontinental migration flows in Eurasia for two main economic reasons. First, population pressures, especially in South Asia and to some extent in East Asia, will remain relatively high, while in Europe, the CIS and Japan populations will stagnate or 
even decline (see Figure 2 above). The latter set of countries with aging populations will to some extent have to draw on the labor supply of younger populations of the former countries if they want to avoid serious imbalances between their working age and old-age populations. Second, income and wage differentials will remain very significant between the industrialized sub-regions and the developing sub-regions, even as with more rapid economic growth in the latter, these differentials will become somewhat less severe over time.

However, restrictive labor market and migration policies, grounded in the economic, cultural and political realities of the potential receiving countries, will act as serious barriers to labor mobility across borders in Eurasia. This in turn will lead to countervailing capital flows and relocation of jobs, including through progressive outsourcing, to the cheaper labor areas of Eurasia. Some fears and tensions around these issues are already evident today. Even in the new EU member countries there are fears that multinationals, who had originally located their production facilities in Central Europe due to relative labor cost advantage, will now move their plants progressively to Asia, especially India and China. More generally, the tensions in Europe around this dilemma - admitting more migrants or losing more jobs - are a political reality today. They will become more pronounced, as the distances across the Eurasian super-continent effectively become shorter and shorter.

\section{Communication and Knowledge Sharing}

One of the key factors in shrinking distances has been the development of modern communication and information technology. The most important element has been undoubtedly the development of the internet and internet connectivity. Eurasia is no exception in this regard. Figure 19 shows the degree of internet penetration and growth in access for different sub-regions in Eurasia. Not surprisingly, Europe and Japan have the highest penetration rates, but the highest growth rates are in the other sub-regions, albeit from relatively low levels. Continued rapid growth in connectivity can be expected, as there have been significant improvements in the super-continent's coverage by communications satellite footprints.

Special programs have been put in place to support connectivity, particularly in poorly served sub-regions, and institutions and programs have developed to provide access to world-wide knowledge, communication and learning. For example, the "Virtual Silk Highway Project”, which has been organized, with the support of the NATO Science Division and other donors and institutions, provides internet access to the South Caucasus and Central Asian CIS countries. ${ }^{27}$ By making available satellite access and providing support for the development of country-based networks of internet providers the project is designed to increase information access in these land-locked countries. The WorldBank sponsored Global Development Learning Network (GDLN) has established learning centers in most of the countries of the Eurasia Region (and in the rest of the world), with video and internet access around the globe that permits and supports

\footnotetext{
${ }^{27}$ See the website http://www.silkproject.org/.
} 
distance learning and conferencing activities on a significant scale. ${ }^{28}$ They can serve for global, regional and sub-regional communication and learning activities. The "Development Gateway" and its country and regional internet portals assure instant access to country-specific, regional and global knowledge and communication. ${ }^{29}$ For Eurasia of particular interest is the "Central Asian Gateway" which serves as a portal for sub-regional information exchange and cooperation. ${ }^{30}$

\section{Figure 19: Eurasian Internet Growth and Penetration}

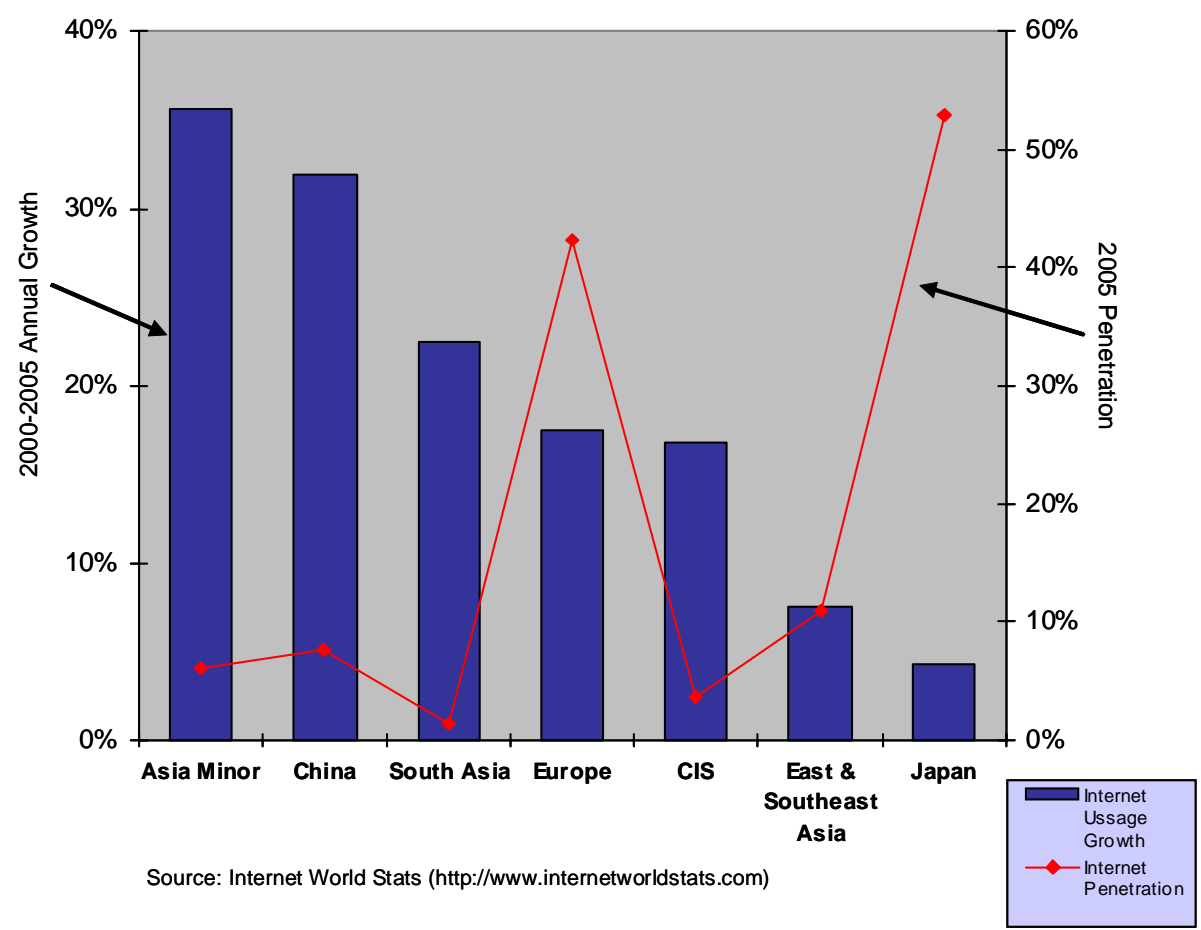

These are just some of the many examples of how modern IT technology affords instant access to information around the globe and around the huge Central Asia super-continent. Of course, IT technology permits improved communication in many other ways that will help integrate Eurasia. For example, it permits more efficient customs clearance for transit traffic by electronic information sharing among border posts within and across countries (as for example in the previously cited project for trade and transit facilitation in South East Europe). Private enterprises, among them banks, transport companies and others engaged in transnational business, will of course make use of modern IT facilities in an ever expanding way. As connectivity increases throughout the Eurasian region, huge geographic distances will matter less and less.

\footnotetext{
${ }^{28}$ See the website http://www.gdln.org/index.html .

${ }^{29}$ See the website http://home.developmentgateway.org/

${ }^{30}$ See the website http://www.cagateway.org/
} 


\section{The Institutional Infrastructure and Politics of Regional Cooperation and the Future of Regional Integration in Eurasia}

In the preceding sections we have documented intensifying trends towards integration of economic activity and communication across Eurasia. Despite these trends, there is currently no overarching institutional framework for regional cooperation, nor should we expect that there will be one soon. However, overlapping initiatives for sub-regional cooperation and integration are expanding throughout the region. These are both a result of the increased economic integration and a factor driving closer integration.

Here are some prominent examples of regional cooperative institutions, none of which however is all-encompassing for Eurasia as a whole:

- ASEM (the Asia-Europe Meeting) is the largest group with 39 members, encompassing the (now-enlarged) EU members, all ASEAN countries and China, Japan and South Korea; CIS and South Asia are not members (see Figure 36);

- The European Union (EU) with 25 members is the most integrated sub-regional grouping, and with its planned further accessions in South East Europe will further increase its reach. The EU's "Neighborhood Policy” extends to six CIS countries as well as a number of North-African and Middle Eastern countries.

- The CIS is a loose assembly of 13 republics of the Former Soviet Union.

- Various smaller sub-regional groupings involve members of the CIS and some of their Eurasian neighbors; most notable are the Shanghai Cooperation Organization (SCO) with China, Russia and four Central Asian members (Turkmenistan is not a member), the Central Asia Cooperation Organization (CACO) with the same membership as SCO minus China; and the Economic Cooperation Organization (ECO), which includes the five Central Asian countries plus Afghanistan, Azerbaijan, Iran, Pakistan and Turkey.

- Various East and South East Asian groupings, especially ASEAN and SAARC.

- In addition, there are a number of regional groupings supported by or involving multilateral institutions, such as the UN regional economic commissions for Europe (ECE) and Asia (ESCAP), the European Bank for Reconstruction and Development (EBRD) and the Asian Development Bank (ADB). They, as well as the World Bank, have in recent years become increasingly active in supporting sub-regional cooperation and integration initiatives. The Greater Mekong Subregion (GMS) and the Central Asia Regional Economic Cooperation (CAREC) initiatives are prime examples of sub-regional cooperation efforts supported by multilateral institutions. Indeed, most aid donors active in the developing countries of Eurasia have now designed sub-regional approaches and strategies in key sub-regions (especially for Central Asia).

Many of these sub-regional institutional frameworks do not appear to be operationally focused, in terms of supporting, funding and implementing specific programs and projects designed to support the effective integration of the sub-regions or to address key issues of Eurasia-wide concern (such as integration of the transport, transit, and energy infrastructure and regulatory frameworks). However, these interlocking forums do 
provide for regular contact and exchange at heads-of-state and at ministerial levels. This itself helps to build trust, smoothes key bilateral relations, and over the long term probably supports selected initiatives that help with sub-regional and even Eurasia-wide integration.

This political and policy dialogue at the highest governmental level among the countries of Eurasia is important not least because it may help answer a key question about the future of cooperation and integration in Eurasia: Will the unquestionable gains from economic integration and the increased interdependency, as well as a shared need for economic stability and prosperity among Eurasian countries drive increased political cooperation and peaceful coexistence in the region? Or will long-standing political tensions and new competition for scarce resources, especially for energy, create regional instability and divisions and, with this, serious barriers to the quick economic integration of Eurasia?

There certainly are many sources of potential conflict within the region: In East Asia there are the tensions around North Korea, the competition between China and Japan, and the simmering tension between China and its Province of Taiwan. In South Asia, there is the long-standing conflict between India and Pakistan. Add to this the unstable situation in Afghanistan, the persistent tensions over Iran and the deep-seated and violent conflicts of the rest of the Middle East, which can spill over in many different ways into the Eurasian political scene. In the CIS there is the potential for conflicts in the South Caucasus and for new unrest in Central Asia, and the latent competition between China and Russia. Even in Europe, there difficulties with further EU enlargement, especially around Turkey's accession, and problems with the EU's strict control over its borders. All these possible sources of conflict might destabilize important parts of Eurasia with spill-over effects for the rest of the region and even globally.

Fortunately, there have been increased efforts within Eurasia to address many of these issues: The EU has become more actively engaged in its dialogue with key regional players, including China, Russia, Iran, and in the context of key sub-regional initiatives (ASEM, EU Neighborhood, the TACIS Central Asia regional strategy, etc.). Both China and Russia have shown increased interest in an engagement in Central Asia. China and Russia, as well as other regional players, have been supportive of the post-9/11 engagement of the US and of NATO in Afghanistan with the goal of a peaceful, democratic and prosperous nation. India and Pakistan not only show signs of wanting to settle their long standing Kashmir conflict, but also are increasingly looking to cooperate over access to the energy sources of Iran, Central Asia and Russia. ASEAN and China in November 2004 agreed to closer cooperation in moving towards the creation of a free trade zone between them. ${ }^{31}$ These tendencies towards peaceful cooperation bode well for a stable long-term future for Eurasia and for continued economic integration.

\footnotetext{
${ }^{31}$ As reported in China Daily, 30 November 2004. http://www.chinadaily.com.cn/english/doc/200411/30/content_395778.htm .
} 


\section{Conclusions and Policy Implications}

While the evidence on Eurasian economic integration that we have been able to assemble so far remains partial and fragmentary, we conclude that over the last 20 years there has been a remarkable process of establishing ever closer and more complex economic links throughout this enormous region. No doubt these trans-Eurasian links are not yet nearly as tight as they are across the Atlantic or the Pacific. But the trends are unmistakable: for better - in some cases for worse - economic integration in Eurasia will continue at a fast pace with the potential of catching up in terms of intensity with the economic integration that characterized transatlantic, transpacific and trans-American economic relations. While competition for energy resources and long-standing political tensions may complicate and in some areas slow down this process, we are hopeful that Eurasia will find peaceful and cooperative solutions for these tensions. Ultimately there is much to be gained for all concerned, both within the region and globally. Indeed, the economic integration and political cooperation across the Atlantic and the Pacific over the last 50 years - against the backdrop of many violent conflicts of the past and despite the competition and occasional tension among the partners - are pointing towards a similar outcome in Eurasia as a distinct and hopeful possibility.

What are the policies that can help bring about this favorable scenario?

- Major investments in transcontinental and sub-regional infrastructure are required to support increased regional trade and communication.

- These investments need to be accompanied by improvements in and harmonization of the policy and regulatory regimes across countries for transit of goods, services and people. Also important are "behind-the-border" reforms, especially improvements in the investment climate, more effective public administration and reduction in corruption.

- Early universal membership in the WTO is preferable to reinforcing the "spaghetti bowl" of (sub-)regional trade agreements.

- Major investments in energy production and transport are needed, but should be matched by cross-border agreements on regulation and by measures to improve efficiency of energy use so as to reduce pressures on energy prices and on the environment. Also, region-wide agreements are necessary to address competing claims for access to regional energy resources by key players (EU, China, India, Japan, US).

- There is a need for a serious review of current illicit drug control policies regionwide with a view towards combating or at least better managing the use, production and trafficking of illicit drugs.

- A better understanding and a clear vision are needed for the role of migration in Eurasia as a means to support the long-term stable and prosperous development of the various sub-regions, those with demographic deficits as well as those with population surpluses.

- Private and public networks of knowledge, business and civil society groups should increasingly take a transcontinental view for Eurasia as a whole, rather than clinging to purely country or sub-regional perspectives. Of course this should not be to the exclusion of linking with global as well as trans-oceanic networks. 
The key actors in bringing about these policy actions are in the first instance the governments of the largest countries in the region. For the immediate future, it is likely that the EU will have to play a lead role in opening up a Eurasia-wide perspective of cooperation and integration. However, for the longer-term, there is no question that the quartet of China, EU, India and Russia represents the key players that need to cooperate constructively and deliberately in supporting the effective integration of Eurasia. Together they will have to pay particular attention to ensure that the fragile border regions of the South Caucasus and of Central Asia become stable and prosperous parts of an integrated Eurasia; and that the shared problems of an unstable and conflict-ridden Middle East neighborhood and of a poor and fractious Africa to the South are effectively addressed by the world community.

If the key players in Eurasia each take on constructive roles in shaping a common transcontinentally integrated economy, then the US can and should restrict itself to play a relatively minor, supportive role. Should intra-Eurasian political frictions prevail, then a more active role by the US might be needed to help settle such conflicts in a peaceful and least disruptive manner.

More generally, in view of the inevitable growth of China and India as strong economic and political players, and in view of the emergence of a new super-continental economic bloc inn Eurasia, it would be desirable to develop global economic and political steering mechanisms that help bind all major players together into a cooperative institutional structure for managing a highly integrated but multi-polar world community. One way to achieve this is to expand the membership of the Group of 8 (G8) summit mechanism, for example by raising the current ministerial-level G20 to a summit-level mechanism. ${ }^{32}$

Finally, key multilateral institutions, such as the UN agencies, the World Bank and the regional development banks, will have to play an active role in helping the regional integration of Eurasia, both at the sub-regional and at the overarching regional level. This will require cooperation among these agencies. But it will also require within these agencies a clearer vision and action to cut across the frequently constraining internal bureaucratic boundaries of regional and sub-regional organizational units. There are encouraging signs that this is beginning to happen, but more concerted and effective steps of inter-agency and internal cooperation are needed.

\footnotetext{
32 The G20 consists of the major industrial and emerging market economies. It currently brings together ministers of finance and central bank governors, but there are proposals to elevate the G20 into summitlevel forum. (Bradford and Linn, 2004)
} 


\section{$\underline{\text { References }}$}

Aitken, Brian J. and Harrison, Ann E. "Do Domestic Firms Benefit from Direct Foreign Investment? Evidence from Venezuela,” American Economic Review, Vol. 89, Issue 3, pp. 605-618, 1999.

Akiner, Shirin, “Regional Cooperation in Central Asia,” Economic Developments and Reforms in Cooperation Partner Countries: The Interrelationship Between Regional Economic Cooperation, Security and Stability, edited by Patrick Hardouin, Reiner Weichhardt, Peter Sutcliffe. NATO Colloquium, Romania. May, 2001.

Babetskii, Ian, Oxana Babetskaia-Kukharchuk and Martin Raiser, “How deep is your trade? Transition and international integration in eastern Europe and the former Soviet Union.” EBRD Working Paper No. 83. 2004.

Bajpaee, Chietigj, "Setting the Stage for a New Cold War: China's Quest for Energy Security", Power and Interest News Report, PINR, 25 February 2005, http://pinr.com/report.php?ac=view_report\&report_id=272\&language_id=1

Blank, Stephen, “India’s Energy Offensive in Central Asia.” Analyst, March 9, 2005, Central Asia-Caucasus Institute, Johns Hopkins University, http://www.cacianalyst.org/view_article.php?articleid=3117

BP, BP Statistical Review of World Energy 2004, June 2004.

Bradford, Colin I. Jr. and Johannes F. Linn, "Global Economic Governance at a Crossroads: Replacing the G-7 with the G-20”, Washington: The Brookings Institution, Policy Brief \#131, April 2004.

Campos, Nauro F. and Kinoshita, Yuko. "Foreign Direct Investment as Technology Transferred: Some Panel Evidence from the Transition Economies,” The Manchester School, Vol. 70 No. 3, pp. 398-419, June 2002.

Carstensen, Kai and Toubal, Farid, "Foreign direct investment in Central and Eastern European countries: a dynamic panel analysis," Journal of Comparative Economics, Volume 32, Issue 1, Pages 3-22, March 2004.

Chow, Edward C., "Russian Pipelines: Back to the Future?” The Georgetown Journal of International Affairs. Issue 51: Winter/Spring 2004.

Cohen, Ariel, “Russian Oil after YUKOS: Implications for the United States.” Executive Memorandum No. 961, The Heritage Foundation, Washington DC, February 28, 2005.

Cornell, Svante E., "Stemming the Contagion: Regional Efforts to Curb Afghan Heroin's Impact”, Georgetown Journal of International Affairs, Winter/Spring 2005, pp. 23-31 
Paula R. Newberg, “A Drug-Free Afghanistan Not So Easy”, Yale Global Online, 7 March 2005, http://yaleglobal.yale.edu/display.article?id=5385

Crane, Keith, Title TBD, Journal of Post Soviet Geography, 2005 forthcoming

Diener, Alexander C., "Homeland conceptions and ethnic integration among

Kazakhstan's Germans and Koreans, ” Mellen Studies in Geography, Vol. 13, Lewiston, NY, Mellen Press, 2004.

EBRD, Transition Report 2003, London, 2003

Energy Information Administration - EIA (U.S. Government), Azerbaijan Country Analysis Brief, November 2004 (2004a).

Energy Information Administration - EIA (U.S. Government), Caspian Sea Region Country Analysis Brief, December 2004 (2004b).

Energy Information Administration - EIA (U.S. Government), China Country Analysis Brief, July 2004 (2004c).

Energy Information Administration - EIA (U.S. Government), Kazakhstan Country Analysis Brief, November 2004 (2004d).

Energy Information Administration - EIA (U.S. Government), Major Russian Oil and Natural Gas Pipeline Projects, January 2005 (2004e).

European Commission, "Helping to Tackle Non-Tariff Trade Barriers in South East Europe” Report to the Stability Pact Working Group on Trade, September, 2004.

Freinkman, Lev, Evgeny Polyakov, and Carolina Revenco. Trade Performance and Regional Integration of the CIS Countries. The World Bank, 2004.

Hare, Paul, Alan Bevan, Jon Stern and Saul Estrin. "Supply Responses in the Economies of the Former Soviet Union.” Discussion Paper No. 2000/09. Edinburgh: Centre for Economic Reform and Transformation, Department of Economics, Heriot-Watt University, December 2000.

Hill, Fiona and Gaddy, Clifford. The Siberian Curse: How Communist Planners left Russia Out in the Cold Washington: The Brookings Institution Press 2003

Hill, Fiona, “Energy Empire: Oil, Gas and Russia’s Revival,” The Foreign Policy Centre, September 2004a.

Hill, Fiona, “Pipelines in the Caspian: Catalyst or Cure-all?,” The Georgetown Journal of International Affairs. Issue 51: Winter/Spring 2004b. 
Hopkirk, Peter Foreign Devils on the Silk Road: The search for the lost cities and treasures of Chinese Central Asia. London: Murray. 1980.

Hu, Albert G.Z and Jefferson, Gary, H. "FDI Impact and Spillover: Evidence from China's Electronic and Textile Industries,” The World Economy, Vol. 25, pp. 1063-1076, 2002.

Irinnews, “Central Asia: Special Report on Labor Migrants in Russia,” 13 July, 2004.

Janssen, Susanne. Deutsche in Russland und Russlanddeutsche in den USA (1871-1928): Die politische, sozio-ökonomische un kulturelle Adaption einer ethnischen Gruppe im Kontext zweier Staaten. Studien zu Geschichte, Politik und Gesellschaft Nordamerikas, John F. Kennedy-Institut für Nordamerikastudien, Freie Universität Berlin, LIT Verlag, Münster, Germany, 1997.

Kazakhstan, “Kazakhstan News Bulletin”, December 30, 2004 Vol. 1, No. 58, Embassy of the Republic of Kazakhstan to the USA and Canada, www.kazakhembus.com

Kelly, John. The Great Mortality. An Intimate History of the Black Death, the Most Devastating Plague of All Time. Harper Collins, 2005.

Linn, Johannes F., "Economic (Dis)Integration Matters: The Soviet Collapse Revisited,” prepared for a conference on "Transition in the CIS: Achievements and Challenges" at the Academy for National Economy, Moscow, September, 2004.

Linn, Johannes F., "The Economic Ties that Bind” Current History, November 2004, pp. 370-375.

Meyer, Klaus E. and Nguyen, Hung Vo. "Foreign Investment Strategies and Sub-national Institutions in Emerging Markets: Evidence from Vietnam,” Journal of Management Studies, Vol. 42, No. 1, pp. 63-93, January 2005.

Min, Pyong Gap, Mass Migration to the United States: Classical and Contemporary Periods. Walnut Creek, CA, AltaMira Press, 2002.

Mitra, Pramit. "Indian Diplomacy Energized by Search for Oil”, YaleGlobal, 14 March 2005. http://yaleglobal.yale.edu/display.article?id=5419

Muzafarov, Damir R., "Problems of Economic Integration in Central Asia, "Economic Developments and Reforms in Cooperation Partner Countries: The Interrelationship Between Regional Economic Cooperation, Security and Stability, edited by Patrick Hardouin, Reiner Weichhardt, Peter Sutcliffe. NATO Colloquium, Romania. May, 2001.

NEA Transport Research and Training (2002), "Trade and Transport Facilitation Audit Turkmenistan”, A Report for the World Bank, Washington, DC. 
NIRA National Institute for Research Advancement, Grand Design for Stability and Prosperity in Northeast Asia. KRI International Corporation, Tokyo 2001

Newberg, Paula R., “A Drug-Free Afghanistan Not So Easy”, Yale Global Online, 7 March 2005, http://yaleglobal.yale.edu/display.article?id=5385

OECD, “Trends in International Migration,” 2002, www.oecd.org/dataoecd

Osmonaliev, Kairat, "Developing Counter Narcotics Policy in Central Asia: Legal and Political Dimensions.” Silk Road Paper, January 2005, Central Asia-Caucasus Institute Silk Road Studies Program, SAIS, Washington, DC.

Oxford Analytica, Eastern Europe and European Union: Border Barriers. February, 2005.

Rose, Andrew, “One Money, One Market? The Effect of Common Currencies on International Trade,” Economic Policy, 2000.

Schnitzer, Monika. "Debt vs. Foreign Direct Investment: The Impact of Sovereign Risk on the Structure of International Capital Flows,” Economica, Vol. 69, pp. 41-67, 2002.

Siddiqi, Toufiq A., “India and Pakistan: Pipe Dream or Pipeline of Peace?,” The Georgetown Journal of International Affairs. Issue 51: Winter/Spring 2004.

Swanstrom, Niklas, "Multilateralism and Narcotics Control in Central Asia.” CEF Quarterly, February 2005, pp. 5-15

UNESCAP (2003), Transit Transport Issues in Landlocked and Transit Developing Countries, Landlocked Developing Countries Series, No.1, United Nations, New York United Nations, International Migration 2002, UN Population Division, October 2002 United Nations Office on Drugs and Crime (UNODC), World Drug Report 2004, Vienna, 2004 www.unodc.org

Wang, M. Y. and Meng, X. C. “Global-local initiatives in FDI: The experience of Shenzhen, China” Asia Pacific Viewpoint, 45 (2), pp. 181-196, 2004

Weatherford, John Genghis Khan and the Making of the Modern World New York: Three River Press, 2004

Wilson, Dominic and Purushothaman, Roopa "Dreaming with the BRICs: The Path to 2050” Goldman Sachs, Global Economic Paper No. 99, October 2003.

World Bank, Regional Electricity Export Potential Study, Washington, DC, December 2004. 
World Bank, Georgia, an Integrated Trade Development Strategy (Report No.27264-GE), Washington, DC, 2003.

World Bank, Ukraine Trade Policy Study Report \#29684, Washington, DC, 2004a

World Bank, Moldova Trade Diagnostic Study, Washington, DC, 2004b

World Bank, Regional Electricity Export Potential Study, Washington, DC, December $2004 c$

World Bank, Global Economic Prospects 2005: Trade, Regionalism, and Development, Washington, DC, 2005

World Trade Organization, Committee on Regional Trade Agreements. Mapping of Regional Trade Agreements (WT/REG/W/41), October 2000. 